\title{
The influence of air-sea exchange on the isotopic composition of oceanic carbon: Observations and modeling
}

\author{
Jean Lynch-Stieglitz ${ }^{1}$ \\ Lamont-Doherty Earth Observatory and Department of Geological Sciences, Columbia University, New York
}

Thomas F. Stocker

Physics Institute, University of Bern, Bern, Switzerland

Wallace S. Broecker and Richard G. Fairbanks

Lamont-Doherty Earth Observatory and Department of Geological Sciences, Columbia University, New York

\begin{abstract}
Although the carbon isotopic composition of ocean waters after they leave the surface ocean is determined by biological cycling, air-sea exchange affects the carbon isotopic composition of surface waters in two ways. The equilibrium fractionation between oceanic and atmospheric carbon increases with decreasing temperature. In Southern Ocean Surface Waters this isotopic equilibration enriches $\delta^{13} \mathrm{C}$ relative to the $\delta^{13} \mathrm{C}$ expected from uptake and release of carbon by biological processes alone. Similarly, surface waters in the subtropical gyres are depleted in $\delta^{13} \mathrm{C}$ due to extensive air-sea exchange at warm temperatures. Countering the tendency toward isotopic equilibration with the atmosphere (a relatively slow process), are the effects of the equilibration of $\mathrm{CO}_{2}$ itself (a much faster process). In regions where there is a net transfer of isotopically light $\mathrm{CO}_{2}$ from the ocean to the atmosphere (e.g., the equator) surface waters become enriched in ${ }^{13} \mathrm{C}$, whereas in regions where isotopically light $\mathrm{CO}_{2}$ is entering the ocean (e.g., the North Atlantic) surface waters become depleted in ${ }^{13} \mathrm{C}$. A compilation of high quality oceanic $\delta^{13} \mathrm{C}$ measurements along with experiments performed using a zonally averaged three-basin dynamic ocean model are used to explore these processes.
\end{abstract}

\section{Introduction}

Although it has been generally accepted that the distribution of $\delta^{13} \mathrm{C}$ of oceanic carbon is primarily controlled by biological cycling of ${ }^{13} \mathrm{C}$ depleted organic matter [Kroopnick, 1985], only recently has attention been focused on the effects of air-sea exchange on oceanic $\delta^{13} \mathrm{C}$ [Oppo and Fairbanks, 1989; Charles and Fairbanks, 1990]. Broecker and Maier-Reimer [1992] and Charles et al. [1993] show how deep and intermediate water $\delta^{13} \mathrm{C}$ is influenced by air-sea exchange in the regions of water mass formation. The effect of air-sea exchange on surface ocean $\delta^{13} \mathrm{C}$ has been demonstrated using multibox models [Keir, 1991; 1993] as well as a general circulation model [Broecker and Maier-Reimer, 1992]. It is important to fully understand the distribution of oceanic $\delta^{13} \mathrm{C}$ in the ocean because it is one of the few chemical signals from past oceans that is reliably recorded by foraminifera and preserved in the sediment record. As such, foraminiferal $\delta^{13} \mathrm{C}$ has been and will continue to be widely used to infer past states of the oceanic carbon cycle.

\footnotetext{
${ }^{1}$ Now at Woods Hole Oceanographic Institution, Woods Hole, Massachusetts.

Copyright 1995 by the American Geophysical Union.
}

Paper number 95GB02574.

0886-6236/95/95GB-02574\$10.00
Here, we re-examine some previously published highquality oceanic $\delta^{13} \mathrm{C}$ measurements in order to evaluate the relative strengths of air-sea exchange and biological cycling in various oceanic regimes. In addition, we use a twodimensional ocean model which includes a carbon cycle [Wright and Stocker, 1992; Stocker et al., 1994] to examine the influence of air-sea exchange and to test our inferences about the effects of these processes in the real ocean. The twodimensional model is ideal for such experiments in that it allows for the quick (relative to a full general circulation model) exploration of various scenarios which require up to 8000 years of integration for a steady state distribution of the carbon isotopic ratio, while retaining some essential aspects of the ocean circulation.

\section{Controls on $\delta^{13} \mathrm{C}$ of Oceanic Carbon}

\section{Biological Control}

During photosynthesis, organisms preferentially take up the lighter isotope of carbon $\left({ }^{12} \mathrm{C}\right)$ increasing surface ocean $\delta^{13} \mathrm{C}$. When the isotopically light organic material is remineralized, the $\delta^{13} \mathrm{C}$ of seawater dissolved inorganic carbon $\left(\mathrm{\Sigma CO}_{2}\right)$ decreases. This fractionation of about $-19 \%$ for marine photosynthesis leaves the nutrient depleted surface ocean with a high $\delta^{13} \mathrm{C}$, and the nutrient enriched deep waters with a low $\delta^{13} \mathrm{C}$. If this process were the only one responsible 
for the distribution of $\delta^{13} \mathrm{C}$ in the ocean, $\delta^{13} \mathrm{C}$ of oceanic $\mathrm{CO}_{2}$ would decrease by approximately $1.1 \%$ for every $1 \mu \mathrm{mol} \mathrm{kg}-1$ increase in oceanic $\mathrm{PO}_{4}$ [Broecker and Maier-Reimer, 1992]. Since oceanic $\mathrm{PO}_{4}$ values have a range of about $3 \mu \mathrm{mol} \mathrm{kg}-1$, biological controls have the potential to produce a $3.3 \%$ range in oceanic $\delta^{13} \mathrm{C}$ values. This linear relationship between $\mathrm{PO}_{4}$ and $\delta^{13} \mathrm{C}$ depends on a constant $\mathrm{C} / \mathrm{P}$ ratio in organic material of 128 , and a constant $\delta^{13} \mathrm{C}$ fractionation of $-19 \%$ relative to oceanic carbon. However, in reality, the discriminaton against ${ }^{13} \mathrm{C}$ during photosynthesis increases from about $19 \%$ in the warm surface ocean to about $30 \%$ in the Antarctic. The computed $\delta^{13} \mathrm{C}$ versus $\mathrm{PO}_{4}$ slope due to biologic processes alone in Antarctic Surface Waters would then be about $-1.7 \% / \mu \mathrm{mol} \mathrm{kg}^{-1}$ instead of the average ocean slope of $-1.1 \% o / \mu \mathrm{mol} \mathrm{kg}^{-1}$. Rau et al. [1989] attribute the low $\delta^{13} \mathrm{C}$ of organic material in the Southern Ocean to the increased pool of aqueous $\mathrm{CO}_{2}$ in these cold waters. This means that at times in the past when atmospheric $\mathrm{CO}_{2}$ was different, the $\delta^{13} \mathrm{C}$ of organic material formed in the surface ocean could have changed [Rau et al., 1989; 1991], causing changes in the slope of $\delta^{13} \mathrm{C}$ versus $\mathrm{PO}_{4}$ relationship for uptake and decay of organic matter. The production of calcium carbonate shells by surface organisms and the subsequent dissolution of this shell material at depth will also affect the distribution of $\delta^{13} \mathrm{C}$ within the ocean. However, since this carbonate has an isotopic composition similar to the seawater in which it grew, the impact of this process on oceanic $\delta^{13} \mathrm{C}$ distributions is very small.

\section{Equilibrium Fractionation During Air-Sea Exchange}

Carbon isotope fractionation during air-sea exchange is also an important factor in determining the isotopic composition of carbon in surface seawater. If the $\mathrm{CO}_{2}$ in the atmosphere were in isotopic equilibrium with the dissolved inorganic carbon $\left(\left[\Sigma \mathrm{CO}_{2}\right]=\left[\mathrm{HCO}_{3}{ }^{-}\right]+\left[\mathrm{CO}_{3}{ }^{-}\right]+\left[\mathrm{CO}_{2}(\mathrm{aq})\right]\right)$ in the ocean, the dissolved inorganic carbon would be enriched in ${ }^{13} \mathrm{C}$ relative to the atmospheric $\mathrm{CO}_{2}$ by about $8 \%$ at $20^{\circ} \mathrm{C}$ [Inoue and Sugimura, 1985; Zhang et al., 1995]. This enrichment is the result of the dominance of $\mathrm{HCO}_{3}{ }^{-}$(about 90 $\%$ of $\Sigma \mathrm{CO}_{2}$ ) with its enrichment relative to the atmosphere of $8.5 \%$ [Mook et al., 1974] with smaller contributions from $\mathrm{CO}_{3}=$ (about $10 \%$ of $\Sigma \mathrm{CO}_{2}$ ) at $6 \%$ enriched relative to the atmospheric value [Zhang et al., 1995] and still smaller contributions (about $1 \%$ of $\Sigma \mathrm{CO}_{2}$ ) of $\mathrm{CO}_{2}$ (aq) which is depleted by about $1 \%$ relative to the atmosphere [Vogel et al., 1970]. All of these equilibrium fractionation factors depend on the temperature of equilibration, with the $\mathrm{HCO}_{3}{ }^{-}$and, thus $\Sigma \mathrm{CO}_{2}$, becoming more enriched relative to the atmospheric value by about $0.1 \%$ per degree of cooling [Mook et al., 1974]. If the surface ocean were in complete isotopic equilibrium with atmospheric $\mathrm{CO}_{2}$, the $30^{\circ} \mathrm{C}$ range in ocean temperatures would cause a $3 \%$ range in oceanic $\delta^{13} \mathrm{C}$, similar to the magnitude of $\delta^{13} \mathrm{C}$ change induced by biological processes. The relationships between the equilibrium isotopic fractionation factors for each dissolved species relative to the atmosphere is summarized in Figure 1.

For a $50-\mathrm{m}$ deep mixed layer it would take about 10 years to equilibrate carbon isotopes between the atmosphere and the ocean (Figure 2), 10 times longer than for $\mathrm{CO}_{2}$ itself

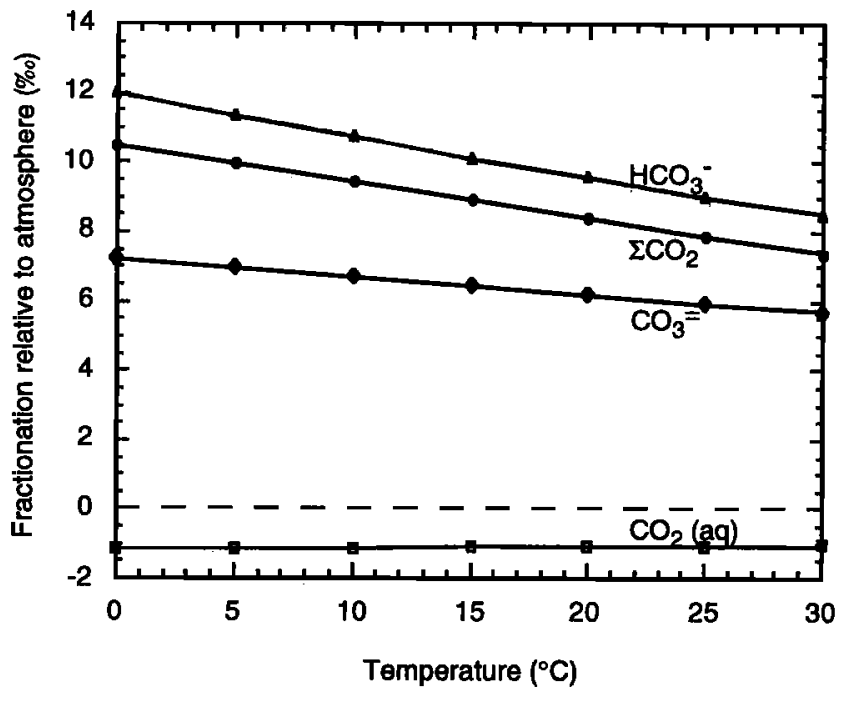

Figure 1. Equilibrium isotopic fractionation of seawater dissolved carbon species relative to atmospheric $\mathrm{CO}_{2}$. Fractionation factors are from Mook et al. [1974], Vogel et al. [1970] and Zhang et al. [1995].

[Broecker and Peng, 1974; Tans, 1980]. This is the result of the fact that $\Sigma \mathrm{CO}_{2}$ can equilibrate with the atmosphere through exchanges between the atmospheric $\mathrm{CO}_{2}$ and $\mathrm{CO}_{2}(\mathrm{aq})$ and $\mathrm{CO}_{3}=$ pools (about $10 \%$ of $\Sigma \mathrm{CO}_{2}$ ), but for carbon isotopic $\left(\delta^{13} \mathrm{C}\right.$ of $\left.\Sigma \mathrm{CO}_{2}\right)$ equilibrium, all $\Sigma \mathrm{CO}_{2}$ must eventually exchange with the atmosphere. Because surface waters move about and are replaced on faster timescales than this, there is no region of the ocean where surface ocean carbon is in complete isotopic equilibrium with the atmosphere $[$ Broecker and Peng, 1982; Broecker and Maier-Reimer, 1992].

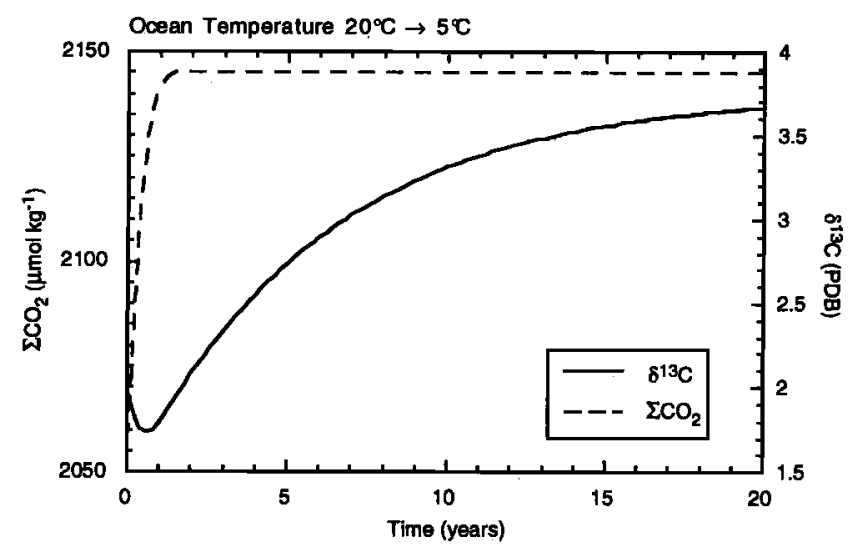

Figure 2. Results of a one-box mixed layer carbon cycle model which illustrates the effects of cooling the surface ocean on surface ocean $\delta^{13} \mathrm{C}$ and $\Sigma \mathrm{CO}_{2}$. The box is taken to be $50 \mathrm{~m}$ deep and exchanges only with the atmosphere. Model equations for air-sea exchange are the same as those for the two-dimensional ocean circulation model. Alkalinity is held constant at $2300 \mu \mathrm{eq}$, atmospheric $\mathrm{pCO}_{2}$ is held at $280 \mu \mathrm{atm}$, and atmospheric $\delta^{13} \mathrm{C}$ is held constant at $-6.5 \%$. Temperature is decreased from $20^{\circ} \mathrm{C}$ to $5^{\circ} \mathrm{C}$ at time $=0$. Surface ocean $\delta^{13} \mathrm{C}$ takes about 10 times longer to reach the new equilibrium values than does surface ocean $\Sigma \mathrm{CO}_{2}$. 
The influence of isotopic equilibration on the $\delta^{13} \mathrm{C}$ of $\Sigma \mathrm{CO}_{2}$ will depend not only on physical properties within the ocean but on biological processes as well. For example, if biological processes bring the $\delta^{13} \mathrm{C}$ of $\Sigma \mathrm{CO}_{2}$ closer to equilibrium with atmospheric carbon (e.g., biological drawdown in cold waters which will elevate $\delta^{13} \mathrm{C}$ ), the subsequent impact of air-sea exchange on this water mass will be lessened. On the other hand, if biological processes tend to bring $\delta^{13} \mathrm{C}$ farther from equilibrium with the atmosphere, the impact of air-sea exchange will be much greater. This process is illustrated by Zahn and Keir [1994] using a box model which includes biological cycling, but imposes isotopic fractionation for air-sea exchange that is independent of temperature. For this model, the $\delta^{13} \mathrm{C}$ is lower than would be predicted from biological cycling alone in the low nutrient surface waters (low latitude and North Atlantic) where biological processes tend to raise $\delta^{13} \mathrm{C}$, and higher than would be predicted for high nutrient surface waters (Southern Ocean) where biological cycling alone would cause low $\delta^{13} \mathrm{C}$.

\section{Effects of Invasion and Evasion of Atmospheric $\mathrm{CO}_{2}$}

The exchange of isotopically light (relative to oceanic $\Sigma \mathrm{CO}_{2}$ ) atmospheric $\mathrm{CO}_{2}$ and surface ocean $\mathrm{CO}_{2}(\mathrm{aq})$ has the potential to leave oceanic carbon depleted in ${ }^{13} \mathrm{C}$ in areas of $\mathrm{CO}_{2}$ invasion (e.g., high northern latitudes, low $\mathrm{pCO}_{2}$ surface waters), and enriched in ${ }^{13} \mathrm{C}$ in areas of the ocean where $\mathrm{CO}_{2}$ is outgassed (e.g., equatorial upwelling, high $\mathrm{pCO}_{2}$ surface waters). As atmospheric $\mathrm{CO}_{2}$ invades the ocean $\left(\mathrm{\Sigma CO}_{2}\right.$ equilibration) and enters the $\mathrm{CO}_{2}$ (aq) pool, the isotopic composition of the $\Sigma \mathrm{CO}_{2}$ becomes lower, because the increase in $\Sigma \mathrm{CO}_{2}$ directly results from the increase in isotopically lighter $\mathrm{CO}_{2}$ (aq). Similarly, it is the isotopically lighter $\mathrm{CO}_{2}$ (aq) that leaves the oceanic carbon pool when $\mathrm{CO}_{2}$ evades to the atmosphere, leaving the remaining $\Sigma \mathrm{CO}_{2}$ enriched in ${ }^{13} \mathrm{C}$. This can be thought of as a Rayleigh-type distillation, which occurs when the phase leaving the bulk solution $\left(\mathrm{CO}_{2}(\mathrm{aq})\right)$ has an equilibrium isotopic composition that is offset from the bulk solution $\left(\Sigma \mathrm{CO}_{2}\right)$. After $\Sigma \mathrm{CO}_{2}$ has reached a new equilibrium concentration, the $\delta^{13} \mathrm{C}$ of $\Sigma \mathrm{CO}_{2}$ will eventually also re-equilibrate with the atmosphere, but as discussed above, this process takes about 10 times as long as $\mathbf{\Sigma} \mathrm{CO}_{2}$ equilibration. A simple one-box mixed layer model illustrates the effects of invasion/evasion of isotopically light $\mathrm{CO}_{2}$ and the eventual return to isotopic equilibrium (Figure 3). As discussed above, the time surface waters spend at one temperature is short enough that carbon isotopic equilibration with the atmosphere is never achieved. So, in the areas where oceanic $\mathrm{pCO}_{2}$ is greater than that of the atmosphere, that is, areas which lose $\mathrm{CO}_{2}$ to the atmosphere (like the equator), $\delta^{13} \mathrm{C}$ of $\Sigma \mathrm{CO}_{2}$ will be enriched by this process, and in areas where oceanic $\mathrm{pCO}_{2}$ is less than that of the atmosphere, that is, where the ocean gains $\mathrm{CO}_{2}$ (like the North Atlantic), the $\delta^{13} \mathrm{C}$ of $\Sigma \mathrm{CO}_{2}$ should be correspondingly depleted.

The largest gain of atmospheric $\mathrm{CO}_{2}$ by surface waters due to the natural, unperturbed carbon cycle are found in the far North Atlantic $\left(+100 \mu \mathrm{mol} \mathrm{kg} \mathrm{kg}^{-1}\right)$, where nutrient (and biologically linked $\Sigma \mathrm{CO}_{2}$ ) poor waters are cooled rapidly, increasing the solubility of $\mathrm{CO}_{2}$ [Broecker and Peng, 1992]. Areas where carbon rich waters are upwelled at low latitudes,
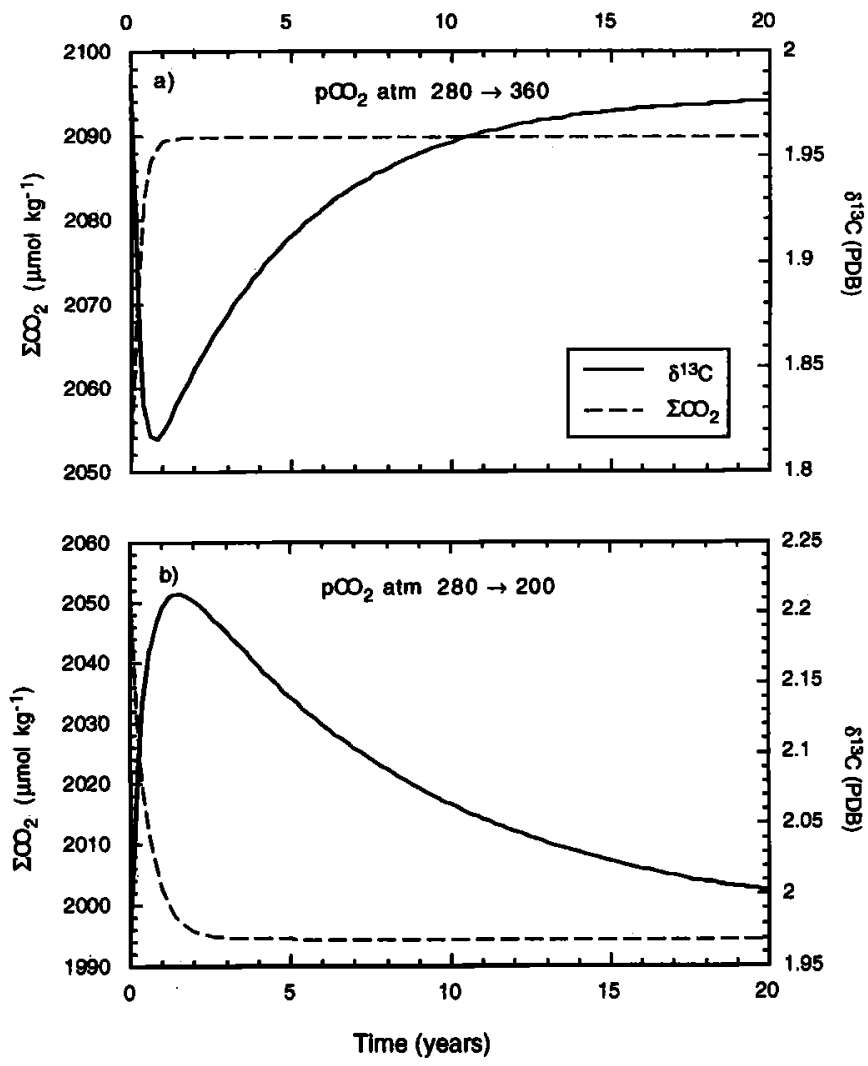

Figure 3. (a) Results of a one-box mixed layer carbon cycle model which illustrates the effects of the invasion of $\mathrm{CO}_{2}$ into the surface ocean. The box is taken to be $50 \mathrm{~m}$ deep and exchanges only with the atmosphere. Model equations for airsea exchange are the same as those for the two-dimensional ocean circulation model. Alkalinity is held constant at 2300 $\mu \mathrm{eq}$, and temperature is set at $20^{\circ} \mathrm{C}$. Atmospheric $\delta^{13} \mathrm{C}$ is held constant at $-6.5 \%$. Atmospheric $\mathrm{pCO}_{2}$ is increased at time $=$ 0 years from 280 to $360 \mu \mathrm{atm}$. The relatively quick equilibration of $\Sigma \mathrm{CO}_{2}$ (invasion of atmospheric $\mathrm{CO}_{2}$ ) causes a lower oceanic $\delta^{13} \mathrm{C}$ until $\delta^{13} \mathrm{C}$ returns to equilibrium. (b) Identical to (a) except that $\mathrm{pCO}_{2}$ is decreased at time $=0$ years from 280 to $200 \mu \mathrm{atm}$. The resulting evasion of $\mathrm{CO}_{2}$ from the ocean causes a temporary rise in oceanic $\delta^{13} \mathrm{C}$ until equilibrium is once again established.

the equatorial Pacific and Arabian Sea, show losses of carbon $\left(-25 \mu \mathrm{mol} \mathrm{kg}{ }^{-1}\right)$ to the atmosphere. The gain of $100 \mu \mathrm{mol} \mathrm{kg}-1$ of carbon from the atmosphere in the North Atlantic would induce a change of $-0.5 \%$ in surface water $\delta^{13} \mathrm{C}\left(\delta^{13} \mathrm{C}\right.$ of invading $\mathrm{CO}_{2}$ is $10 \%$ lighter than surface ocean $\delta^{13} \mathrm{C}$; invasion of $\mathrm{CO}_{2}$ will cause an increase of $5 \%$ in size of the surface $\mathrm{\Sigma CO}_{2}$ reservoir). The total range in the amount of carbon that has been gained or lost to the atmosphere throughout the ocean is about $125 \mu \mathrm{mol} \mathrm{kg} \mathrm{kg}^{-1}$ [Broecker and Peng, 1992], which would induce a range of about $0.6 \%$ in surface waters due to this effect. This is a small but significant effect when compared with the changes due to air-sea isotopic equilibration and biological cycling.

Both physical and biological processes within the ocean will influence the location and intensity of the invasion and evasion of carbon to/from the ocean and thus impact the changes in oceanic $\delta^{13} \mathrm{C}$ due to this invasion/evasion. The 
physics of ocean circulation will produce gradients in surface ocean $\mathrm{pCO}_{2}$ with higher $\mathrm{pCO}_{2}$ at the equator where waters are upwelled and warmed, and low $\mathrm{pCO}_{2}$ in polar regions where waters are cooled. These patterns are modified by biological processes which intensify the high $\mathrm{pCO}_{2}$ at the equator because the upwelled waters contain extra carbon from the organic material that has been re-mineralized into the water since it has left the surface. Similary, the tendency for physical processes (temperature) to produce a negative $\mathrm{pCO}_{2}$ anomaly in the Southern Ocean is somewhat diminished due to the large amounts of carbon in this nutrient-rich water.

\section{Kinetic Fractionation During $\mathrm{CO}_{2}$ Exchange}

Because $\mathrm{CO}_{2}$ exchange between the ocean and atmosphere is not an equilibrium process, with some regions of the ocean degassing $\mathrm{CO}_{2}$ and others absorbing $\mathrm{CO}_{2}$, we must also consider the kinetic isotopic fractionation factors involved in these one-way transfers. The transfer of $\mathrm{CO}_{2}$ across the air-sea interface involves the processes of molecular diffusion. All else being equal, heavier $\mathrm{CO}_{2}$ molecules (those containing ${ }^{13} \mathrm{C}$ ) will diffuse more slowly than lighter molecules (those containing ${ }^{12} \mathrm{C}$ ). Theory [Siegenthaler and Munnich, 1981] predicts that the $\mathrm{CO}_{2}$ leaving the ocean (for a sea-to-air transfer) will be depleted in the heavy isotope by about $0.5 \%$ in addition to the equilibrium fractionation, and similarly, the $\mathrm{CO}_{2}$ leaving the atmosphere (for an air-to-sea transfer) will be depleted in the heavy isotope by about $0.5 \%$ relative to the equilibrium fractionation. Experiments [Inoue and Sugimura, 1985; Wanninkhof, 1985; Jähne et al., 1987] suggest kinetic fractionation factors between -0.9 and $-1.3 \%$. However, theory predicts kinetic fractionation for a diffusive transfer of gas between the liquid and gas phases, and the laboratory experiments are also performed under such diffusive conditions. In the ocean, where the gas transfer is more turbulent, the kinetic fractionation will be less, and in the extreme case of air-sea transfer via bubble injection, there will be no kinetic fractionation [Knox et al., 1992]. In either case, the effects of kinetic fractionation during invasion/evasion are very small and will be masked by the effects of the temperature dependent equilibration and by the invasion/evasion of $\mathrm{CO}_{2}$ which has a lower $\delta^{13} \mathrm{C}$ than oceanic carbon, $\Sigma \mathrm{CO}_{2}$.

\section{Observed Oceanic $\delta^{13} \mathrm{C}$ Distributions Surface Ocean Data}

Although it has been shown that surface ocean $\delta^{13} \mathrm{C}$ lies somewhere in between the biologically predicted value and the value which would be at equilibrium with the atmosphere [Broecker and Peng, 1982; Broecker and Maier-Reimer, 1992], a more detailed examination of the distribution of surface ocean $\delta^{13} \mathrm{C}$ demands high-quality surface ocean $\delta^{13} \mathrm{C}$ and nutrient data in order to determine the relative influence of biological and air-sea exchange processes. Here we will use the $\delta^{13} \mathrm{C}$ data collected along $150^{\circ} \mathrm{W}$ and published by Kroopnick et al. [1977] along with surface $\mathrm{PO}_{4}$ and temperature data from this same cruise. We also use the Southern Ocean Eltanin 1968 surface water $\delta^{13} \mathrm{C}$ transect along $135^{\circ} \mathrm{E}$ [Kroopnick, 1974], again along with surface $\mathrm{PO}_{4}$ and temperature data from this cruise. The Geochemical Ocean
Sections Study (GEOSECS) Indian Ocean $\delta^{13} \mathrm{C}$ measurements with accompanying $\mathrm{PO}_{4}$ and temperature measurements were used, but the $\delta^{13} \mathrm{C}$ data sets from the Atlantic and Pacific GEOSECS expeditions were not included as they exhibited considerably more scatter than the Indian Ocean data set. We also include data from the Transient Tracers in the Ocean (TTO) program in the North Atlantic [Ostlund and Grall, 1987] supplemented by TTO $\delta^{13} \mathrm{C}$ data analyzed at Lamont-Doherty Earth Observatory (Table 1), as well as data from the Weddell Sea and South Atlantic Ocean reported by Mackensen, et al. [1993]. We subtract $0.15 \mu \mathrm{mol} \mathrm{kg}{ }^{-1}$ from the Weddell Sea (PS16) $\mathrm{PO}_{4}$ measurements reported by Mackensen et al. [1993] to bring the $\mathrm{PO}_{4}$ values into agreement with the GEOSECS $\mathrm{PO}_{4}$ for these water masses. Location of transects are shown in Figure 4. The surface ocean $\delta^{13} \mathrm{C}$, temperature, and $\mathrm{PO}_{4}$ data are plotted in Figure 5.

Air-sea exchange and surface water $\delta^{13} \mathbf{C}$. Broecker and Maier-Reimer [1992] show that if there were no air-sea exchange, the relationship between $\delta^{13} \mathrm{C}$ and $\mathrm{PO}_{4}$ in the ocean would be

$$
\left.\delta^{13} \mathrm{C}-\delta^{13} \mathrm{C}^{\mathrm{M} . \mathrm{O} .}=\frac{\Delta_{\text {photo }}}{\Sigma \mathrm{CO}_{2}^{\mathrm{M} . \mathrm{O}}} \frac{\mathrm{C}}{\mathrm{P}}\right)_{\text {org }}\left(\mathrm{PO}_{4}-\mathrm{PO}_{4}^{\mathrm{M} .0}\right)
$$

When reasonable values are substituted $\left(\delta^{13} \mathrm{C}^{\mathrm{M} .0 .}=0.3\right.$, $\left.\Delta_{\text {photo }}=-19 \%, \Sigma \mathrm{CO}_{2}^{\mathrm{M} . \mathrm{O}}=2200 \mu \mathrm{mol} \mathrm{kg} \mathrm{kg}^{-1}, \mathrm{C} / \mathrm{P}\right)_{\mathrm{org}}=128$, $\mathrm{PO}_{4}^{\mathrm{M}} \mathrm{O}=2.2 \mu \mathrm{mol} \mathrm{kg}{ }^{-1}$ ), the predicted relationship between $\delta^{13} \mathrm{C}$ and $\mathrm{PO}_{4}$ closely matches the relationship for waters in the deep Indian and Pacific Oceans $\left(\delta^{13} \mathrm{C}=2.7-1.1 \times \mathrm{PO}_{4}\right)$. This is to be expected, as the effect of air-sea exchange should be constant for these deep waters due to the homogeneity of source waters for the deep Indian and Pacific Oceans. We can determine the degree to which air-sea exchange processes (both the tendency toward isotopic equilibration and the effects of invasion/evasion) have affected surface ocean $\delta^{13} \mathrm{C}$ by subtracting the $\delta^{13} \mathrm{C}$ value predicted from biological cycling alone from the actual $\delta^{13} \mathrm{C}$,

$$
\delta^{13} \mathrm{C}_{\mathrm{as}}=\delta^{13} \mathrm{C}-\left(2.7-1.1 \times \mathrm{PO}_{4}\right) .
$$

This is the same as $\Delta \delta^{13} \mathrm{C}$ defined by Broecker and MaierReimer [1992] but has been renamed $\delta^{13} \mathrm{C}_{\text {as }}$, the air-sea exchange signature, because $\Delta \delta^{13} \mathrm{C}$ has been frequently used in the paleoceanographic community to denote gradients of $\delta^{13} \mathrm{C}$ within the ocean. By definition, water with $\delta^{13} \mathrm{C}_{\text {as }}$ of $0 \%$ has the same air-sea exchange signature as mean ocean deep water. A positive value of $\delta^{13} C_{\text {as }}$ simply means that the water has a higher $\delta^{13} \mathrm{C}_{\mathrm{as}}$ than mean ocean deep water (more of an influence of air-sea exchange at cold temperatures/ less at warm temperatures), where as a negative $\delta^{13} C_{a s}$ value implies less $\delta^{13} \mathrm{C}$ enrichment due to air-sea exchange than for mean ocean deep water. The air-sea exchange signature, $\delta^{13} \mathrm{C}_{\text {as }}$, is not the same as preformed $\delta^{13} \mathrm{C}$, which will be determined both by the effects of air-sea exchange and biological cycling. This formulation for $\delta^{13} \mathrm{C}$ as will only represent the true effects of air-sea exchange if the assumptions about constant $\mathbf{C} / \mathrm{P}$ ratios in organic material, constant $\delta^{13} \mathrm{C}$ of organic material, and reasonable biologically induced changes in oceanic carbon content are sufficiently accurate. In Antarctic Surface Waters where $\delta^{13} \mathrm{C}$ of organic material is substantially lower than for the rest of the ocean, $\delta^{13} \mathrm{C}_{\text {as }}$ will overestimate the effects of air-sea exchange. 
Table 1. TTO $\delta^{13} \mathrm{C}$ Data Analyzed at Lamont-Doherty Earth Observatory

\begin{tabular}{|c|c|c|c|}
\hline Depth, $\mathbf{m}$ & $\delta^{13} \mathrm{C}$ & & \\
\hline \multicolumn{2}{|c|}{ Station 111} & \multicolumn{2}{|c|}{ Station 159} \\
\hline 2 & 1.29 & 11 & 2.03 \\
\hline 50 & 1.25 & 76 & 0.80 \\
\hline 196 & 0.86 & 201 & 0.91 \\
\hline 344 & 0.81 & 301 & 0.73 \\
\hline 494 & 0.80 & 399 & 0.85 \\
\hline 740 & 0.89 & 500 & 0.88 \\
\hline 938 & 0.78 & 600 & 0.84 \\
\hline 1135 & 0.84 & 698 & 0.94 \\
\hline 1330 & 0.82 & 797 & 0.89 \\
\hline 1683 & 0.80 & 949 & 0.99 \\
\hline 1971 & 0.74 & 1049 & 0.95 \\
\hline 2570 & 0.83 & 1148 & 0.99 \\
\hline 3075 & 0.72 & 1248 & 0.98 \\
\hline 3557 & 0.78 & 1349 & 1.05 \\
\hline 4059 & 0.69 & 1547 & 0.87 \\
\hline 4462 & 0.75 & 2140 & 0.85 \\
\hline 4854 & 0.85 & \multicolumn{2}{|c|}{ Station 169} \\
\hline 5246 & 0.77 & 19 & 1.04 \\
\hline 5635 & 0.82 & 149 & 0.62 \\
\hline \multicolumn{2}{|c|}{ Station 116} & 349 & 0.54 \\
\hline 0 & 1.32 & 547 & 0.78 \\
\hline 200 & 0.71 & 747 & 0.83 \\
\hline 303 & 0.70 & 934 & 0.91 \\
\hline 401 & 0.65 & 1032 & 0.92 \\
\hline 499 & 0.73 & 1119 & 0.95 \\
\hline 647 & 0.59 & 1228 & 0.95 \\
\hline 893 & 0.53 & \multicolumn{2}{|c|}{ Station 231} \\
\hline 990 & 0.49 & 9 & 1.52 \\
\hline 1187 & 0.71 & 247 & 1.06 \\
\hline \multicolumn{2}{|c|}{ Station 148} & 397 & 1.03 \\
\hline 9 & 1.60 & 547 & 0.80 \\
\hline 77 & 0.70 & 695 & 0.72 \\
\hline 247 & 0.70 & 843 & 0.75 \\
\hline 444 & 0.68 & 996 & 0.87 \\
\hline 601 & 0.40 & 1191 & 0.88 \\
\hline \multicolumn{2}{|c|}{ Station 156} & 1800 & 0.99 \\
\hline 11 & 1.64 & 2476 & 1.01 \\
\hline 99 & 1.41 & 2583 & 0.98 \\
\hline 199 & 0.94 & 3074 & 0.94 \\
\hline 298 & 0.94 & 3462 & 0.94 \\
\hline 447 & 1.00 & 4060 & 0.99 \\
\hline 1239 & 1.02 & 4454 & 0.93 \\
\hline 1488 & 1.01 & 4844 & 0.90 \\
\hline
\end{tabular}

$\delta^{13} \mathrm{C}$ is referenced to PDB
The data sets used in this study were collected over a span of 21 years (1968 to 1989) during which time the atmospheric $\delta^{13} \mathrm{C}$ has changed from -7.1 to $-7.8 \%$ due to the addition of isotopically light fossil fuel $\mathrm{CO}_{2}$ [Keeling et al., 1989]. Atmospheric $\mathrm{CO}_{2}$ increased from 320 to $351 \mu$ atm during this same time period. So both via isotopic equilibration with an atmosphere which is constantly decreasing in $\delta^{13} \mathrm{C}$, and increased invasion of isotopically light atmospheric $\mathrm{CO}_{2}$ into the surface ocean, we expect $\delta^{13} \mathrm{C}$ and also $\delta^{13} \mathrm{C}_{\text {as }}$ to decrease with time for the data sets we examine, and we expect that "natural" preanthropogenic $\delta^{13} \mathrm{C}$ would be higher than any of the data shown. However, the processes involved in determining the modern ocean $\delta^{13} \mathrm{C}$ should be the same as those which determined $\delta^{13} \mathrm{C}$ in the preindustrial ocean, and the study of these anthropogenically altered $\delta^{13} \mathrm{C}$ data sets should provide insight into these processes.

$\delta^{13} C_{\text {as }}$ is highest in Antarctic Surface Water and in the North Pacific (Figure 5). This enrichment of $\delta^{13} \mathrm{C}$ is most likely due to exchange with the atmosphere at low temperatures. Although evasion of carbon from surface waters can also enrich the surface water $\delta^{13} \mathrm{C}$, in these areas more inorganic carbon has invaded from the atmosphere than is lost to it [Broecker and Peng, 1992], which would tend to decrease $\delta^{13} \mathrm{C}$. Although the residence time of Antarctic Surface Waters is not particularly long (about 2 years, [Gordon, 1988]), this is an area of high winds and thus high gas exchange rates. If we took into account the low $\delta^{13} \mathrm{C}$ of organic material formed in Antarctic Surface Waters, we would obtain a lower $\delta^{13} \mathrm{C}_{\text {as }}$ (by about $0.4 \%$ at the most) which would imply somewhat less intense air-sea exchange at low temperatures to account for the Antarctic Surface Water $\delta^{13} \mathrm{C}$. In all four Antarctic data sets we see high $\delta^{13} C_{a s}$ values in the vicinity of the Antarctic Polar Front, but in the Weddell Sea transect we also see lower $\delta^{13} C_{a s}$ values corresponding to the contribution of upwelled Circumpolar Deep Water $\left(\delta^{13} C_{a s}=0 \%\right.$ ) in the Weddell Gyre. In the North Pacific, gas exchange at low temperatures results in the high $\delta^{13} \mathrm{C}_{\mathrm{as}}$ in the northem end of the Hudson transect.

The lowest values of $\delta^{13} C_{\text {as }}$ are found in the centers of the subtropical gyres. Surface waters circulate in these anticyclonic gyres for a relatively long amount of time giving the oceanic carbon ample time to equilibrate isotopically with the atmosphere at high temperatures despite the relatively low rates of gas exchange. Intermediate $\delta^{13} C_{\text {as }}$ values are found in the Subantarctic Surface Waters which result from a mixture of subtropical surface waters with low $\delta^{13} C_{\text {as }}$ and Antarctic Surface Waters with high $\delta^{13} C_{a s}$ to the south.

The situation in the North Atlantic seems slightly more complex. The $\delta^{13} C_{a s}$ in the subpolar gyre, while higher than the subtropical gyres, is still not as high as cold waters in the North Pacific and Southern Ocean. Air-sea exchange at cold temperatures will tend to raise the $\delta^{13} C_{\text {as }}$ of the northward moving upper waters but is unable to erase the signature of high temperature isotopic exchange from the subtropical gyres. However, also keeping the surface ocean $\delta^{13} \mathrm{C}_{\text {as }}$ low is the invasion of up to $160 \mu \mathrm{mol} \mathrm{kg}{ }^{-1}$ of isotopically light $\mathrm{CO}_{2}$ (both natural and fossil fuel) from the atmosphere (calculated from TTO $\Sigma \mathrm{CO}_{2}, \mathrm{~S}, \mathrm{PO}_{4}, \mathrm{NO}_{3}$, and alkalinity data as by Broecker and Peng [1992]), which will tend to lower $\delta^{13} \mathrm{C}_{\text {as }}$ by $0.7 \%$. In the far North Atlantic the $\delta^{13} C_{\text {as }}$ remains low, 


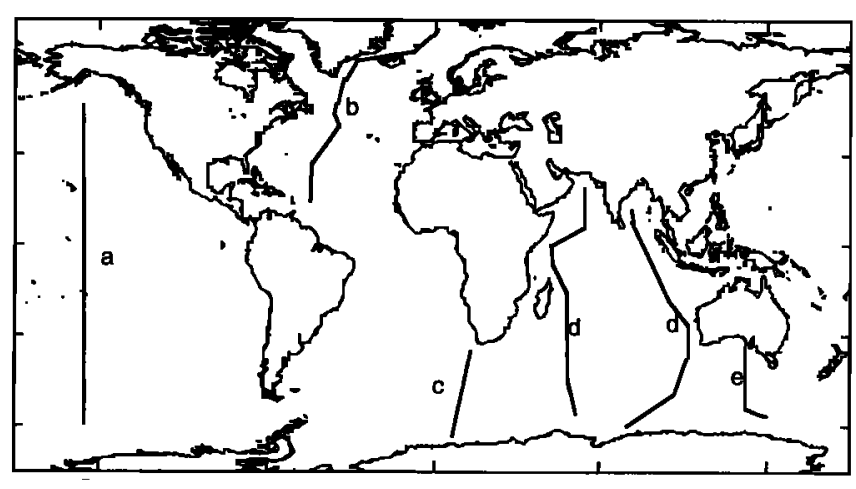

Figure 4. Locations of surface water $\delta^{13} \mathrm{C}$ transects. (a) Hudson, April - May 1970 [Kroopnick et al., 1977], (b) TTO April - October 1981 [Ostlund and Grall, 1987], (c) Polarstern [Mackensen et al., 1993], (d) GEOSECS Indian Ocean Expedition, January - March 1978, (e) Eltanin, July 1968 [Kroopnick, 1974].

reflecting the fact that air-sea exchange at low temperatures cannot mask the effects of $\mathrm{CO}_{2}$ invasion and the remnant low $\delta^{13} C_{\text {as }}$ the northward flowing surface waters may still have from isotopic equilibration at high temperatures.
Biological processes and surface water $\delta^{13} \mathrm{C}$. The $\delta^{13} \mathrm{C}$ of surface water is determined partly by the air-sea exchange processes discussed above, and partly by biological cycling of carbon isotopes. In the Southern Ocean, $\delta^{13} \mathrm{C}$ increases from south to north all the way to the subtropical convergence as predicted by the decrease in $\mathrm{PO}_{4}$ from south to north. However, the $\delta^{13} \mathrm{C}$ rises by less than the full amount predicted by the $\mathrm{PO}_{4}$ concentration, due to the influence of airsea exchange at warmer temperatures to the north. The $\delta^{13} \mathrm{C}$ trend also reflects the biologically predicted trend near the equator (between $10^{\circ} \mathrm{S}$ and $5^{\circ} \mathrm{N}$ on the Pacific transect), indicating that in this region, too, air-sea exchange cannot mask the effects of biological drawdown of isotopically light carbon. However, in the subtropical gyres the trend in $\delta^{13} \mathrm{C}$ shows minima in the central $\mathrm{PO}_{4}$ free portions of the gyre where biological drawdown alone would produce a $\delta^{13} \mathrm{C}$ maximum. In these convergent gyres, air-sea exchange at high temperatures has sufficient time to mask the biological portion of the $\delta^{13} \mathrm{C}$ signal.

\section{Deep Ocean Data}

The distribution of $\delta^{13} \mathrm{C}$ of $\mathrm{\Sigma CO}_{2}$ in the deep ocean primarily reflects the biological regeneration of isotopically light carbon, and, in general, is directly correlated to oxygen
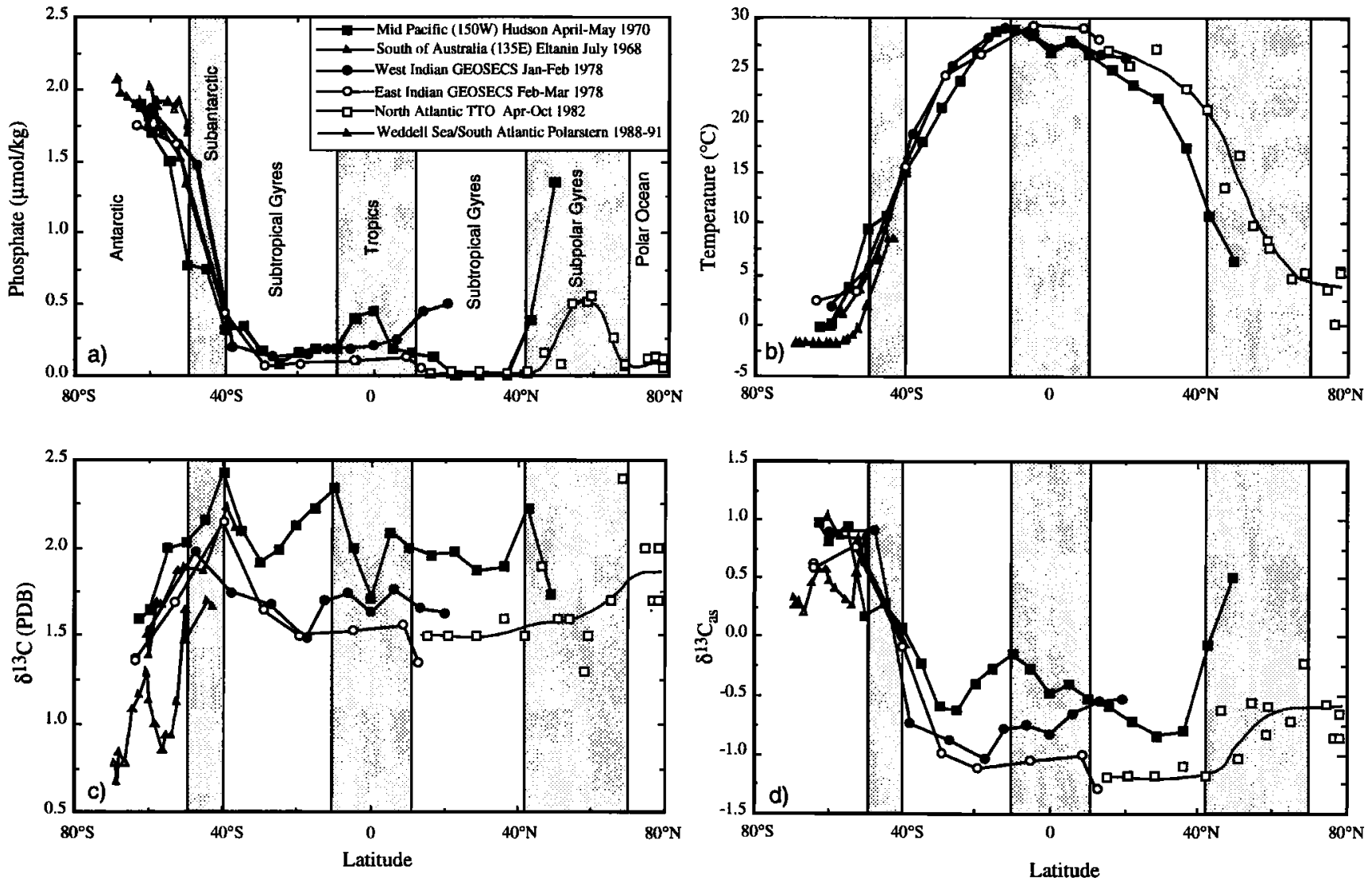

Figure 5. Phosphate, temperature, $\delta^{13} \mathrm{C}$, and $\delta^{13} \mathrm{C}_{\mathrm{as}}$, the air-sea exchange signature from high-quality surface ocean measurements. Polar surface waters have high $\delta^{13} \mathrm{C}_{\text {as }}$ due to air-sea exchange at low temperatures. The lowest $\boldsymbol{\delta}^{\mathbf{1 3}} \mathrm{C}_{\text {as }}$ are observed in the subtropical gyres due to isotopic equilibration at warm temperatures. Equatorial $\delta^{13} \mathrm{C}_{\text {as }}$ is high due to the evasion of isotopically light carbon to the atmosphere combined with insufficient time for isotopic equilibration at warm temperatures. 
concentrations and inversely correlated to nutrient and $\Sigma \mathrm{CO}_{2}$ concentrations [Deuser and Hunt, 1969; Craig, 1970; Kroopnick, 1985]. However, subsurface $\delta^{13} \mathrm{C}$ distributions are also controlled to a significant extent by the air-sea exchange signature imprinted at the surface. Broecker and Maier-Reimer [1992] suggest that North Atlantic Deep Waters (NADW) have lower $\delta^{13} \mathrm{C}$ by $0.4 \%$ than would be predicted for an ocean with no air-sea exchange, and that Weddell Sea Bottom Water (WSBW) is enriched in $\delta^{13} \mathrm{C}$ by $0.2 \%$. Charles et al. [1993] use selected GEOSECS $\delta^{13} \mathrm{C}$ and $\mathrm{PO}_{4}$ profiles to show that these air-sea exchange signatures are carried by deep water throughout the ocean. They also note that Antarctic Intermediate Water which is derived in large part from Antarctic Surface Waters is significantly enriched in $\delta^{13} \mathrm{C}$ due to air-sea exchange at low temperatures. Here we present a compilation of high quality deep water (below $2 \mathrm{~km}$ depth) $\delta^{13} \mathrm{C}$ and $\mathrm{PO}_{4}$ data from all three oceans (Figure 6). This figure is almost identical to the relationship shown by Broecker and Maier-Reimer [1992], except that the WSBW is more enriched in $\delta^{13} \mathrm{C}$ by air-sea exchange $\left(\delta^{13} \mathrm{C}_{\text {as }}=0.4 \%\right.$ o) and does not mix directly with NADW to form the North Atlantic mixing line. Instead, it is a shallower component of Circumpolar Deep Water, a mixture of WSBW, NADW, and returning deep waters from the Pacific, which mixes into the Atlantic Basin via the Vema Passage. As shown by Broecker and Maier-Reimer
[1992], the waters entering the deep Indian and Pacific Oceans derive from shallower (more NADW enriched) points along this North Atlantic mixing line via the Atlantis Passage and the Samoa Passage, respectively.

\section{Modeling Oceanic $\delta^{13} \mathrm{C}$}

\section{Model Description}

In order to fully explore the effects of air-sea exchange and biological processes on oceanic $\delta^{13} \mathrm{C}$, we use the twodimensional dynamic ocean model of Wright and Stocker [1992], as modified and described by Stocker et al. [1994] (state A). The zonally averaged balances of momentum, mass, potential temperature, salt and tracers are solved in the three major basins of the world ocean with realistic surface area and volume $(+/-5 \%)$. The geometry and the numerical grid agree with Stocker et al. [1994] except for an increased vertical resolution (21 levels).

The circulation is driven by east-west pressure differences that are parameterized in terms of the meridional density gradient. Fluxes of heat and freshwater at the surface are obtained by restoring sea surface temperature and salinity to the zonal averages of Levitus [1982]. To compensate for a shallower first layer $(25 \mathrm{~m}$ instead of $50 \mathrm{~m})$, the timescale for the relaxation of temperature and salinity to surface values was

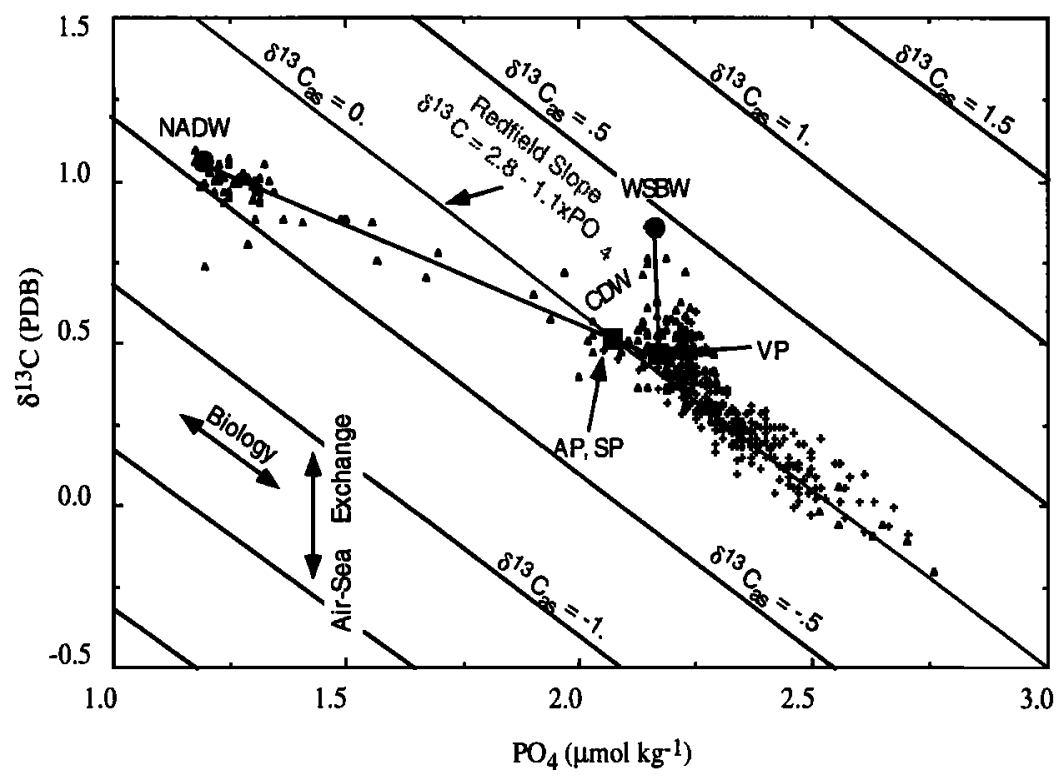

Figure 6. High-quality deep water $\delta^{13} \mathrm{C}$ and $\mathrm{PO}_{4}$ data from below $2000 \mathrm{~m}$ in the Atlantic (triangles), Pacific (squares), and Indian (crosses) Oceans. Data for the Atlantic Ocean includes the GEOSECS data analyzed at Scripps Institution of Oceanography [Kroopnick et al., 1972; Kroopnick, 1980], corrected by subtracting 0.1 \%o from $\delta^{13} \mathrm{C}$ values as suggested by Kroopnick [1980], data analyzed at Lamont-Doherty Earth Observatory from the TTO expedition (Table 1), and data from the Atlantic sector of the Southern Ocean [Mackensen et al., 1993]. Also plotted are GEOSECS Test Station I from the Pacific Ocean [Kroopnick et al., 1970] and all GEOSECS data from the Indian Ocean [Kroopnick, 1985]. Phosphate and $\delta^{13} \mathrm{C}$ data for the GEOSECS stations were obtained from the National Oceanic Data Center. Weddell Sea Bottom Water (WSBW) has high $\delta^{13} C_{\text {as }}$ reflecting the contribution of Antarctic Surface Waters. Circumpolar Deep Water (CDW) reflects the mixing of WSBW with NADW and returning flow from the Pacific and Indian Oceans. Atlantic data reflects mixing between North Atlantic Deep Water (NADW) and CDW which enters the Atlantic via the Vema Passage (VP). Deep waters in the deep Indian and Pacific follow the "Redfield Slope" (parallel lines) reflecting the regeneration of organic material into CDW which enters these oceans via the shallower Atlantis Passage (AP) and Samoa Passage (SP), respectively. 
lowered from 50 to 25 days. The effect of wind stress is included. Properties are exchanged between the ocean basins through the southern ocean where zonal mixing is instantaneous (timescales associated with the deep circulation are much longer than those of recirculation in the Antarctic Circumpolar Current (ACC)).

We further modify the model presented by Stocker et al. [1994], by shutting off the enhanced zonal mixing $\left(K_{H}=K_{d}\right)$ not only south of $40^{\circ} \mathrm{S}$ but across $45^{\circ} \mathrm{N}$ as well. The enhanced zonal mixing is intended to simulate the zonal mixing by gyres, and should not be necessary across the subtropical/subpolar gyre boundary at $45^{\circ} \mathrm{N}$. This modification influences the sea surface temperature field and yields better agreement between modelled and observed $\delta^{13} C_{\text {as }}$ in the North Atlantic.

We use the inorganic carbon cycle described by Stocker et al. [1994]. Total carbon is carried within the ocean as a tracer. Oceanic $\mathrm{pCO}_{2}$ is determined in the surface layer using the chemical equilibria for the carbonate system. In this inorganic model, alkalinity and borate concentration are affected solely by evaporation and precipitation. They can therefore be obtained by scaling to the surface salinity value. The net flux of carbon $\left(F_{\Sigma}\right)$ through air-sea interface is proportional to the difference between surface ocean and atmospheric $\mathrm{pCO}_{2}$ :

$$
\left.\left.F_{\Sigma}=F_{\text {as }}-F_{\text {sa }}=k \mathrm{pCO}_{2}\right)_{\text {ocean }}-k \mathrm{pCO}_{2}\right)_{\mathrm{atm}}
$$

where $k$ is the gas exchange rate, $F_{\text {as }}$ is the flux of carbon from the atmosphere to the ocean, and $F_{\text {sa }}$ is the flux of carbon from the ocean to the atmosphere. We modify the model described by Stocker et al. [1994] to include for a gas exchange rate which is a function of wind speed, $W$, using the relationship from Tans et al. [1994],

$$
k\left(\mathrm{~mol} \mathrm{~m}^{-2} \mathrm{y}^{-1} \mu \mathrm{atm}^{-1}\right)=0.016\left[W\left(\mathrm{~m} \mathrm{~s}^{-1}\right)-3\right]
$$

We use zonally averaged wind speed from the climatology of Esbensen and Kushnir [1981], and the resulting exchange rates are shown in Figure 7. For the experiments which follow, atmospheric $\mathrm{pCO}_{2}$ is not interactive, but is imposed at a constant preanthropogenic value of $280 \mu \mathrm{atm}$.

In addition to total carbon concentration (which is taken here to be the same as ${ }^{12} \mathrm{C}$ concentration due to the much

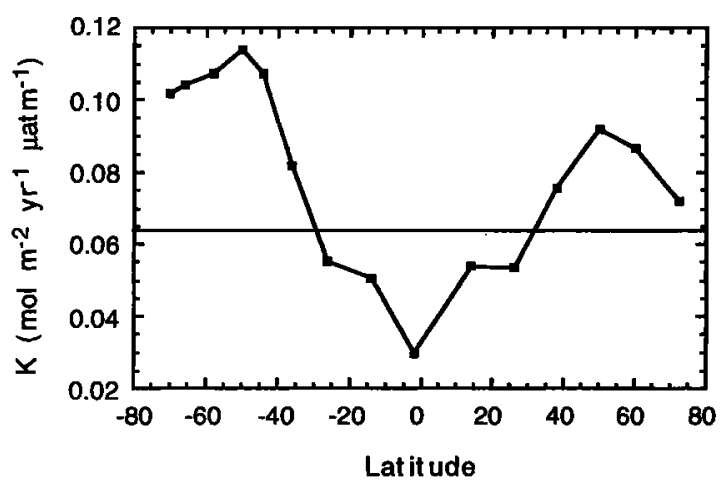

Figure 7. Gas exchange rates, $k\left(\mathrm{~mol} \mathrm{~m}^{-2} \mathrm{y}^{-1} \mu \mathrm{atm}^{-1}\right)$, used in experiments 1,2 , and 4 . The constant gas exchange rate of $0.067 \mathrm{~mol} \mathrm{~m}^{-2} \mathrm{y}^{-1} \mu_{\mathrm{atm}}^{-1}$ used in experiment 4 is also shown for comparison. greater abundance of this isotope), ${ }^{13} \mathrm{C}$ is also carried as a tracer. The flux of ${ }^{13} \mathrm{C}$ into the ocean $\left(F^{13}\right)$ is determined as by Siegenthaler and Munnich [1981]:

$$
F^{13}=\alpha_{\mathrm{as}} F_{\mathrm{as}} R_{\mathrm{a}}-\alpha_{\mathrm{sa}} F_{\mathrm{sa}} R_{\Sigma}
$$

where $R_{a}$ is the ratio of ${ }^{13} \mathrm{C} /{ }^{12} \mathrm{C}$ in the atmosphere and $R_{\Sigma}$ is the ratio of ${ }^{13} \mathrm{C} /{ }^{12} \mathrm{C}$ in oceanic carbon $\left(\Sigma \mathrm{CO}_{2}\right)$. The fractionation factor for air-sea carbon transfer, $\alpha_{a s}=\alpha_{\beta} * \alpha_{k}$, where $\alpha_{\beta}=-0.373 / \mathrm{T}\left({ }^{\circ} \mathrm{K}\right)+1.00019$ [Vogel et al., 1970], is the temperature dependent equilibrium fractionation factor between atmospheric $\mathrm{CO}_{2}$ and surface ocean $\mathrm{CO}_{2}(\mathrm{aq})$, and $\alpha_{\mathrm{k}}=$ 0.9995 [Siegenthaler and Munnich, 1981] is the kinetic fractionation factor for $\mathrm{CO}_{2}$ gas transfer across the air-sea interface. The fractionation factor for sea-air carbon transfer, $\alpha_{\text {sa }}=\alpha_{\Sigma} * \alpha_{k}$. Here $\alpha_{\Sigma}$, the temperature dependent equilibrium fractionation factor between surface ocean $\mathrm{CO}_{2}$ (aq) and total dissolved inorganic carbon $\left(\mathrm{\Sigma CO}_{2}\right)$, is approximated by the equilibration factor between oceanic $\mathrm{CO}_{2}$ (aq) and bicarbonate $\left(\mathrm{HCO}_{3}{ }^{-}\right), \alpha_{\mathrm{HCO}_{3}-}=-9.866 / \mathrm{T}\left({ }^{\circ} \mathrm{K}\right)+1.02412$ [Mook et al., 1974; Vogel et al., 1970]. For various model runs, as noted below, these fractionation factors were altered in order to explore the role of different air-sea exchange processes in determining surface ocean $\delta^{13} \mathrm{C}$. Although the older fractionation factors referenced above are used in all model runs shown, substituting the fractionationation factors presented by Zhang et al. [1995] changes model results only by a small amount (everywhere less than $0.3 \%$ o). Although only ${ }^{12} \mathrm{C}$ and ${ }^{13} \mathrm{C}$ are carried in the model, the carbon isotope ratio is expressed as $\delta^{13} \mathrm{C}\left(\delta^{13} \mathrm{C}(\%)=\left(R / R_{\mathrm{PDB}}-1\right)^{*} 1000\right)$ for model output, where $R$ is the ratio ${ }^{13} \mathrm{C} /{ }^{12} \mathrm{C}$, and $R_{\mathrm{PDB}}$ is this ratio for the reference value (PDB). The $\delta^{13} \mathrm{C}$ of atmospheric $\mathrm{CO}_{2}$ is specified at the preanthropogenic value of $-6.48 \%$ o.

\section{Model Results : Assessing the Role of Air-Sea Exchange}

The inorganic carbon cycle model was run with no modifications (experiment 1 , Table 2 ) in order to assess the effect of air-sea exchange on the distribution of $\delta^{13} \mathrm{C}$.

Table 2. Model Experiments

Experiment Number

Modifications

1

No modifications (full temperature dependent and kinetic fractionation factors, wind speed dependent gas exchange), atmospheric $\mathrm{pCO}_{2}=280$, $\delta^{13} \mathrm{C}=-6.48$

Anthropogenic increase in $\mathrm{CO}_{2}$ and $\delta^{13} \mathrm{C}$ prescribed for atmosphere

Constant gas exchange rate (no wind speed dependence), atmospheric $\mathrm{pCO}_{2}$ $=280, \delta^{13} \mathrm{C}=-6.48$

Fractionation between $\Sigma \mathrm{CO}_{2}$ and $\mathrm{CO}_{2}$ constant (No temperaturedependence $),\left(\alpha_{\mathrm{as}}=0.98940, \alpha_{\mathrm{sa}}=\right.$ 0.99840 ), atmospheric $\mathrm{pCO}_{2}=280, \delta^{13} \mathrm{C}$ $=-6.48$ 
Atmospheric $\mathrm{CO}_{2}$ was fixed at the preindustrial value of 280 $\mu$ atm and the $\delta^{13} \mathrm{C}$ of atmospheric carbon at $-6.48 \%$ [Friedli et al., 1986]. The model was integrated for 10,000 years until a steady state for $\delta^{13} \mathrm{C}$ was reached (Figure 8). The long time required to reach a steady state is due to the fact that carbon isotopes in the surface ocean are not completely equilibrated with the atmosphere. It is therefore necessary for the model to complete several ventilation cycles (at 1000 to 2000 years each) before the waters have been exposed at the surface for a sufficient amount of time for a steady state to be reached. For ease of comparison with modern oceanic $\delta^{13} C_{a s}$ values, $\delta^{13} C_{a s}$ was also calculated for the model by subtracting the model's mean ocean value for $\delta^{13} \mathrm{C}$ from the model predicted $\delta^{13} \mathrm{C}$. Because biological processes are not included in this model, the patterns of $\delta^{13} \mathrm{C}$ and $\delta^{13} \mathrm{C}_{\mathrm{as}}$ will be identical for each model run, but will be offset from one another by a constant amount.

As expected, cold surface waters have high $\delta^{13} \mathrm{C}$, reflecting the equilibration at cold temperatures, and warm surface waters have low $\delta^{13} \mathrm{C}$, with minima in the center of the subtropical gyres, reflecting the relatively long residence of these waters at the warm surface (Figure 9). However, in no area of the ocean is $\delta^{13} \mathrm{C}$ completely in equilibrium with the atmosphere (Figure 9, dashed line), as predicted based on the long time required for carbon isotopic equilibration at a given temperature (about 10 years). The $\delta^{13} \mathrm{C}_{\text {as }}$ of subsurface waters reflects the $\delta^{13} \mathrm{C}_{\mathrm{as}}$ of the source region, with NADW having relatively low $\delta^{13} \mathrm{C}_{\mathrm{as}}$, and Antarctic Bottom Water (AABW) and Antarctic Intermediate Water with higher $\delta^{13} C_{\text {as }}$ (Figure 10). Before comparing model $\delta^{13} \mathrm{C}_{\text {as }}$ with the air-sea exchange signature observed in the real ocean, we must quantitatively assess the impact of the rising atmospheric $\mathrm{CO}_{2}$ and falling atmospheric $\delta^{13} \mathrm{C}$ due to land use changes and fossil fuel emissions over the last several hundred years.

Experiment 2 is started from the steady state preindustrial state (experiment 1) and atmospheric $\mathrm{CO}_{2}$ and $\delta^{13} \mathrm{C}$ are specified to reflect the observed anthropogenic increase. Atmospheric $\mathrm{CO}_{2}$ is prescribed as by Stocker et al. [1994], and $\delta^{13} \mathrm{C}$ is taken to be linearly related to the increase in $\mathrm{CO}_{2}$ (Figure 11). The model is then integrated for 188 more years (1800 - 1988) to obtain the transient distributions of $\delta^{13} \mathrm{C}$ in the inorganic carbon cycle model. In order to calculate $\delta^{13} C_{\text {as }}$

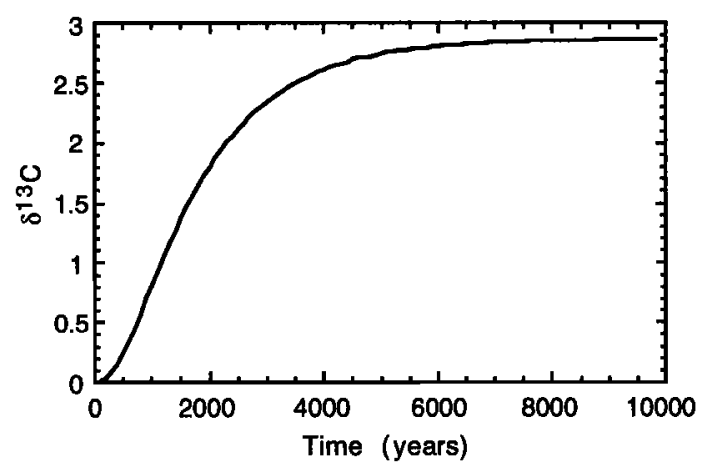

Figure 8. Model values of $\delta^{13} \mathrm{C}$ of $\Sigma \mathrm{CO}_{2}$ for the middepth North Pacific during model spin-up. A steady state is reached for $\delta^{13} \mathrm{C}$ of $\mathrm{\Sigma CO}_{2}$ after the model is integrated for about 8000 years.

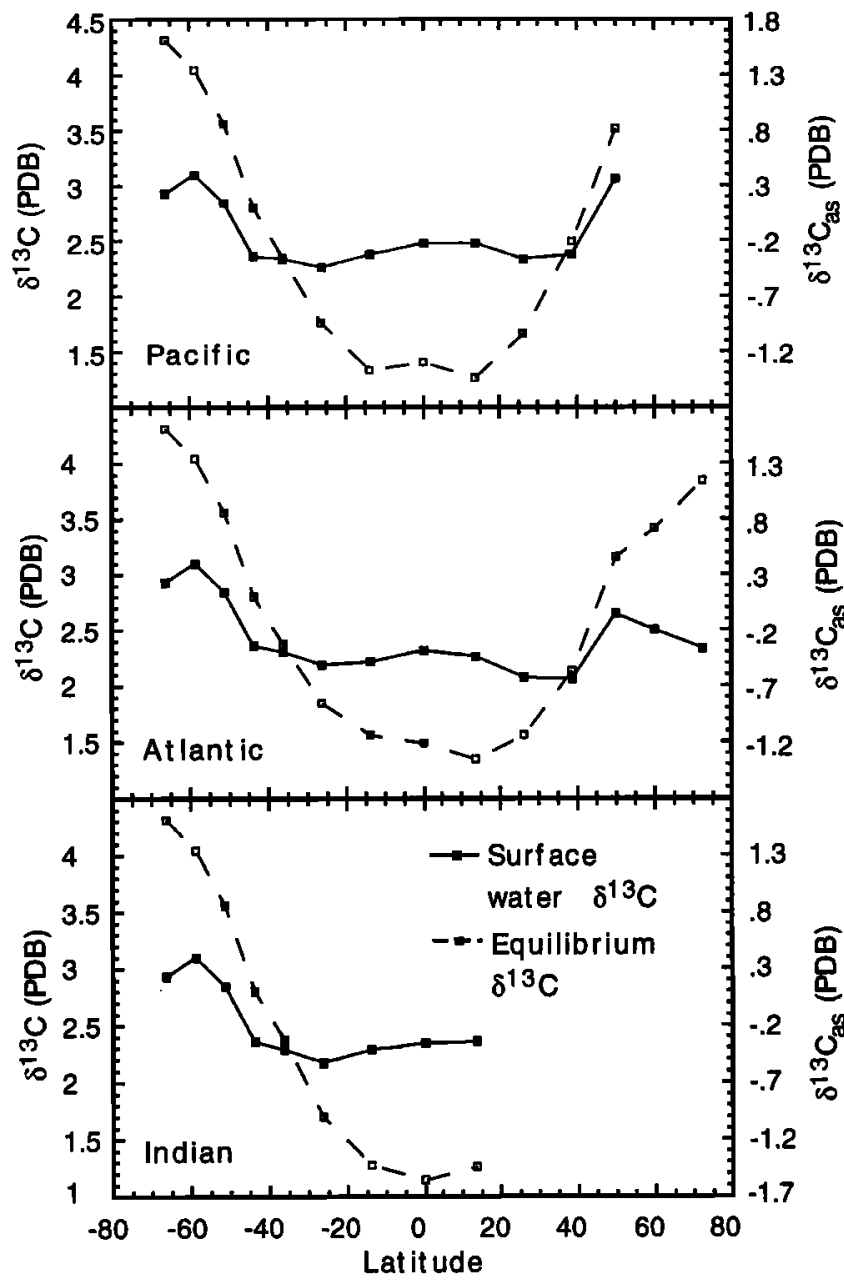

Figure 9. Steady state surface $\delta^{13} \mathrm{C}$ for experiment 1 (solid symbols) along with the $\delta^{13} \mathrm{C}$ predicted if the surface ocean were in complete isotopic equilibrium with the atmosphere (open symbols). This run includes full temperature dependent isotopic fractionation factors, and preindustrial atmospheric $\mathrm{CO}_{2}$ and $\delta^{13} \mathrm{C}$. The air-sea exchange signature (modelled $\delta^{13} \mathrm{C}$ minus modelled mean ocean $\delta^{13} \mathrm{C}$ for this inorganic model) for experiment 1 can be read from the right-hand axis.

in a manner consistent with that for modern measurements, the preanthropogenic (experiment 1) mean ocean $\delta^{13} \mathrm{C}$ is subtracted from model predicted $\delta^{13} \mathrm{C}$. The resulting surface ocean $\delta^{13} C_{\text {as }}$ for 1988 is lower than the preindustrial state (experiment 1 ) by 0.2 to $1.0 \%$, everywhere less than the 1.4 $\%$ change in the atmosphere for this period of time (Figure 12). The model $\delta^{13} \mathrm{C}_{\text {as }}$ values which show the greatest change from the preindustrial state $(1 \%$ ) are in the centers of the subtropical gyres, and those showing the least change $(0.2 \%$ ) are in the Southern Ocean where older deep waters are mixed to the surface due to deep convection in the model. The lower surface water $\delta^{13} \mathrm{C}_{\text {as }}$ for the modern ocean predominantly reflects the equilibration with the lower atmospheric $\delta^{13} \mathrm{C}$, but also reflect the invasion of anthropogenic $\mathrm{CO}_{2}$ into the ocean (Figure 12). Although the values of surface ocean $\delta^{13} \mathrm{C}_{\mathrm{as}}$ change throughout the run, the patterns remain similar to those in the preindustrial run (experiment 1) although slightly exaggerated due to the more effective equilibration with the 

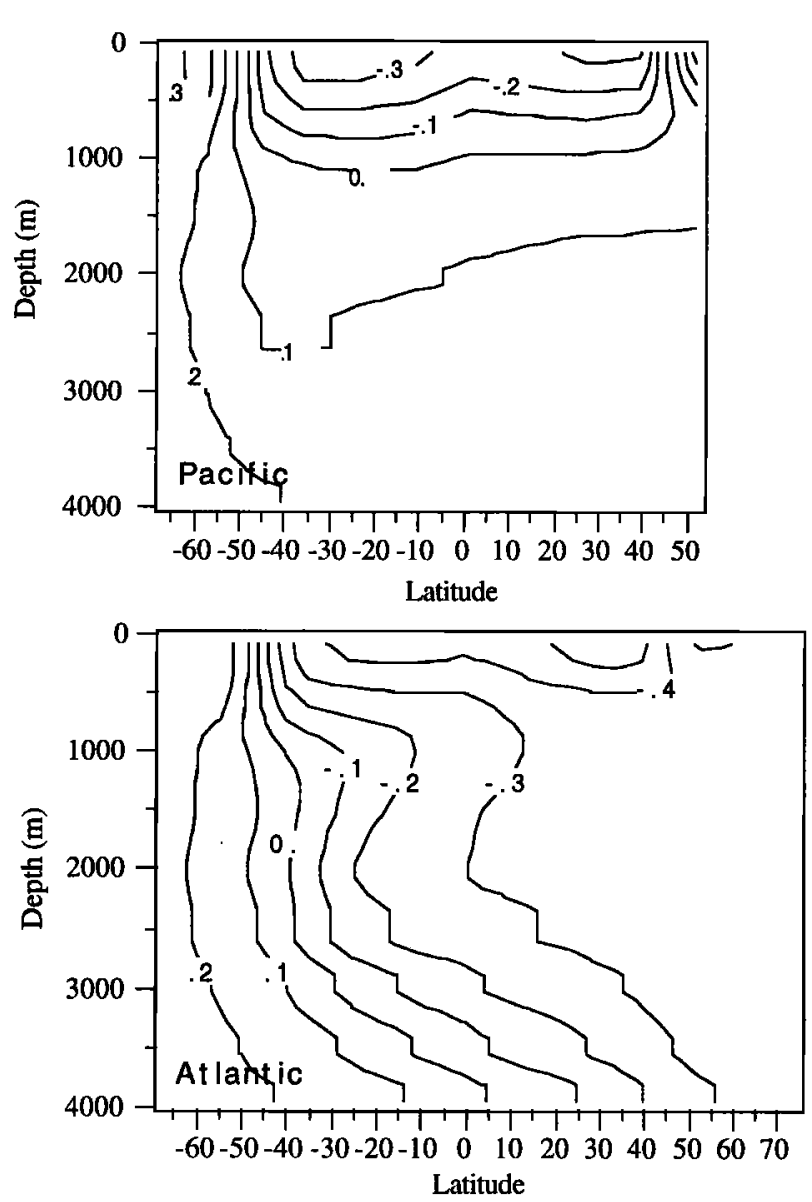

Figure 10. Steady state $\delta^{13} \mathrm{C}_{\mathrm{as}}$ distributions for the Atlantic and Pacific Oceans for experiment 1 (temperature dependent fractionation factors and preindustrial atmosphere).

modern atmosphere in the subtropical gyres than at the poles or equator where older water is being brought to the surface.

The patterns and ranges of $\delta^{13} C_{a s}$ values for surface waters in the inorganic model with full isotopic fractionation factors

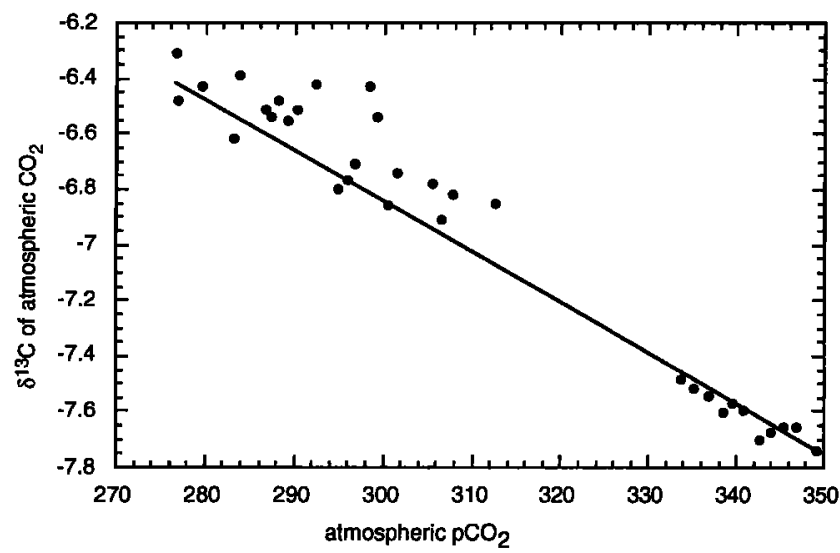

Figure 11. The $\delta^{13} \mathrm{C}$ of atmospheric $\mathrm{CO}_{2}$ for experiment 2 (1800-1988), is assumed to vary linearly with $\mathrm{CO}_{2}$ from the preindustrial value of $-6.48 \%$ at $280 \mu \mathrm{atm}$ [Friedli et al., 1986 ] to $-7.74 \%$ at $350 \mu \mathrm{atm}$ in 1988 [Keeling et al., 1989]. This relationship is shown along with the rest of the $\mathrm{pCO}_{2}$ and $\delta^{13} \mathrm{C}$ data from these publications.

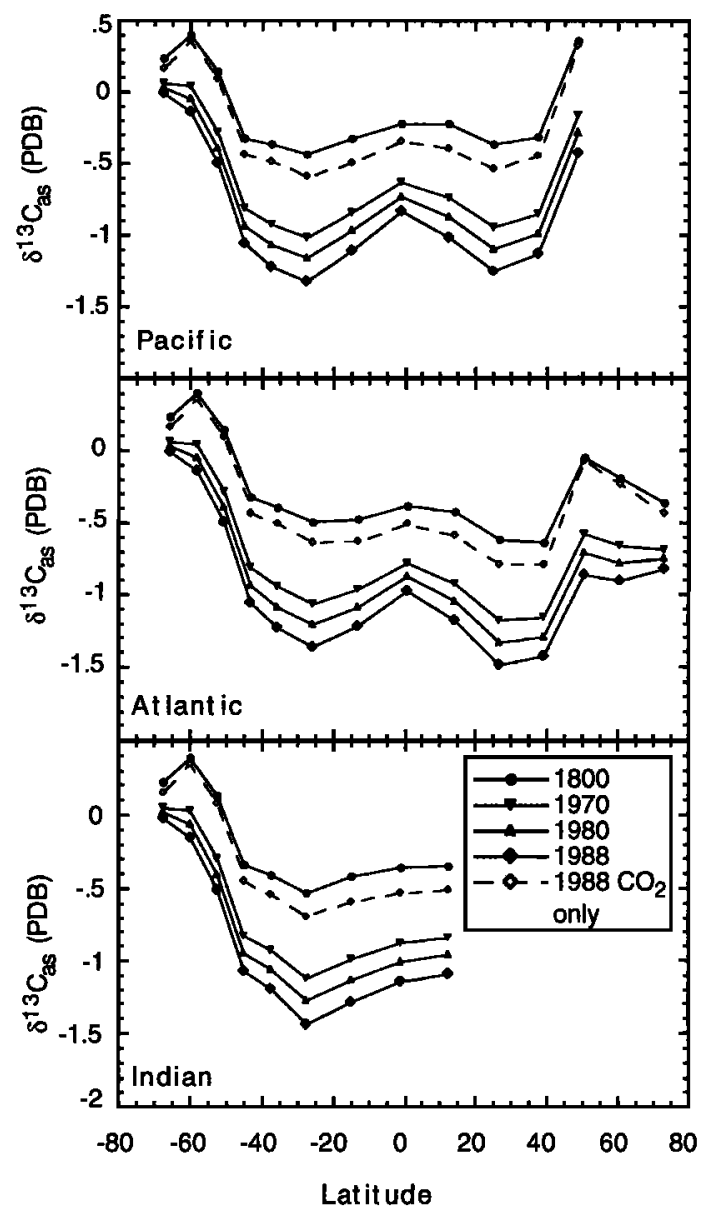

Figure 12. The $\delta^{13} \mathrm{C}_{\text {as }}$ of surface water carbon for experiment 2, which includes the anthropogenic rise in atmospheric $\mathrm{CO}_{2}$ and fall in $\delta^{13} \mathrm{C}$ of atmospheric $\mathrm{CO}_{2}$ (solid lines and symbols). Also plotted is the $\delta^{13} \mathrm{C}_{\mathrm{as}}$ of surface water that results from the rise in atmospheric $\mathrm{CO}_{2}$ alone (invasion effect), with atmospheric $\delta^{13} \mathrm{C}$ held constant (dashed lines, open symbols).

(experiments 1 and 2) look very much like $\delta^{13} \mathrm{C}_{\text {as }}$ calculated from observed $\delta^{13} \mathrm{C}$ and $\mathrm{PO}_{4}$ (Figure 5d). Minimum values are in the subtropical gyres and maximum values are in the Antarctic and North Pacific. As with observed $\delta^{13} C_{a s}, \delta^{13} \mathrm{C}$ in the inorganic model remains low in the North Atlantic despite the low surface temperatures. The relatively high $\delta^{13} C_{\text {as }}$ of Southern Ocean Surface Waters and low $\delta^{13} \mathrm{C}_{\text {as }}$ of North Atlantic Surface Waters are reflected in the high $\delta^{13} \mathrm{C}_{\text {as }}$ of $A A B W$, and the low $\delta^{13} C_{\text {as }}$ of NADW (Figure 10), as in the real ocean (Figure 6).

In experiment 3 , a constant gas exchange rate of $.067 \mathrm{~mol}$ $\mathrm{m}^{-2} \mathrm{yr}^{-1} \mu \mathrm{atm}^{-1}$ is used instead of the zonally varying exchange rate of experiment 1 . The pattern of surface ocean $\delta^{13} \mathrm{C}_{\text {as }}$ predicted by this model run (Figure 13) is very similar to the model with variable gas exchange, and also replicates the airsea exchange signature, $\delta^{13} C_{a s}$, features observed in the real ocean (Figure $5 \mathrm{~d}$ ). The similarity between the distributions of surface ocean $\delta^{13} \mathrm{C}$ in the two model runs (experiments 1 and 4) implies that, to first order, the pattern of surface ocean $\delta^{13} \mathrm{C}_{\mathrm{as}}$ is determined primarily by the temperature and history 


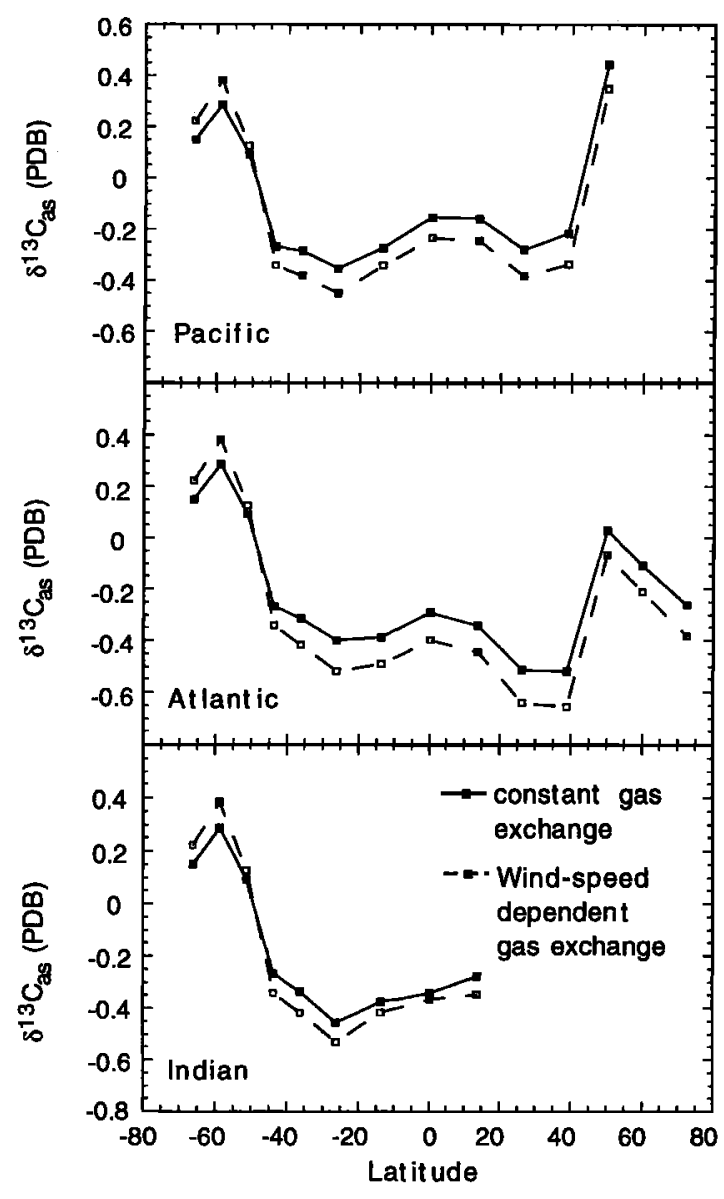

Figure 13. The $\delta^{13} \mathrm{C}_{\text {as }}$ of surface water for experiment 3 , constant gas exchange (solid lines and symbols). Also plotted for comparison is the $\delta^{13} \mathrm{C}_{\text {as }}$ of surface water for experiment 1 , where gas exchange is wind speed dependent (dashed lines, open symbols).

of surface water masses, while geographic variations of gas exchange rates play a secondary role. The absence of enhanced gas exchange rates in the polar regions in this run does result in a slightly lower $\delta^{13} \mathrm{C}_{\mathrm{as}}$ gradient between low and high latitudes.

In experiment 4 , the inorganic carbon cycle model was modified such that there is no temperature dependence to carbon isotope fractionation during air-sea exchange. This experiment demonstrates the effect of invasion and evasion of $\mathrm{CO}_{2}$ on the distribution of carbon isotopes in the world ocean. These effects cause a spread of up to $0.6 \%$ in surface ocean $\delta^{13} C_{a s}$ with high $\delta^{13} C_{a s}$ in warm waters where the evasion of the isotopically lighter $\mathrm{CO}_{2}(\mathrm{aq})$ enriches the surface water $\mathrm{\Sigma CO}_{2}$ in ${ }^{13} \mathrm{C}$ (Figure 14). Polar surface waters in both hemispheres have similar low $\delta^{13} \mathrm{C}$ values reflecting the invasion of $\mathrm{CO}_{2}$ into these cold waters. Note that this differs from the case of the real ocean, where biological cycling will enhance the invasion of $\mathrm{CO}_{2}$ into the North Atlantic where biological processes have depleted surface ocean carbon and mute the invasion of $\mathrm{CO}_{2}$ into the Southern Ocean where already carbon-rich waters upwell. In general, the effects of invasion/evasion alone (high $\delta^{13} \mathrm{C}$ in warm waters, low $\delta^{13} \mathrm{C}$ in cold waters) are opposite in sign to the effects of temperature dependent equilibration with the atmosphere (high $\delta^{13} \mathrm{C}$ in cold waters, low $\delta^{13} \mathrm{C}$ in warm waters).

Although these model experiments give us a first order look at how air-sea exchange will affect the distribution of $\delta^{13} \mathrm{C}$ in the ocean, in the real ocean biological processes will also influence air-sea exchange, and thus the air-sea exchange signature, $\delta^{13} \mathrm{C}_{\mathrm{as}}$, to some extent. When biological cycling is added to this model, we will be able to test the sensitivity of $\delta^{13} \mathrm{C}_{\mathrm{as}}$ to these processes. However, it is clear from the good comparisons between modelled and actual $\delta^{13} \mathrm{C}_{\text {as }}$ that while biological processes are quite important in determining $\delta^{13} \mathrm{C}$, they will have a secondary influence on the air-sea exchange signature, $\delta^{13} \mathrm{C}_{\text {as. }}$.

\section{Conclusions}

Although biological cycling seems to be the primary control on today's deep ocean $\delta^{13} \mathrm{C}$ distribution, air-sea exchange plays an equally important role in determining the $\delta^{13} \mathrm{C}$ of surface ocean carbon. Air-sea exchange controls $\delta^{13} \mathrm{C}$

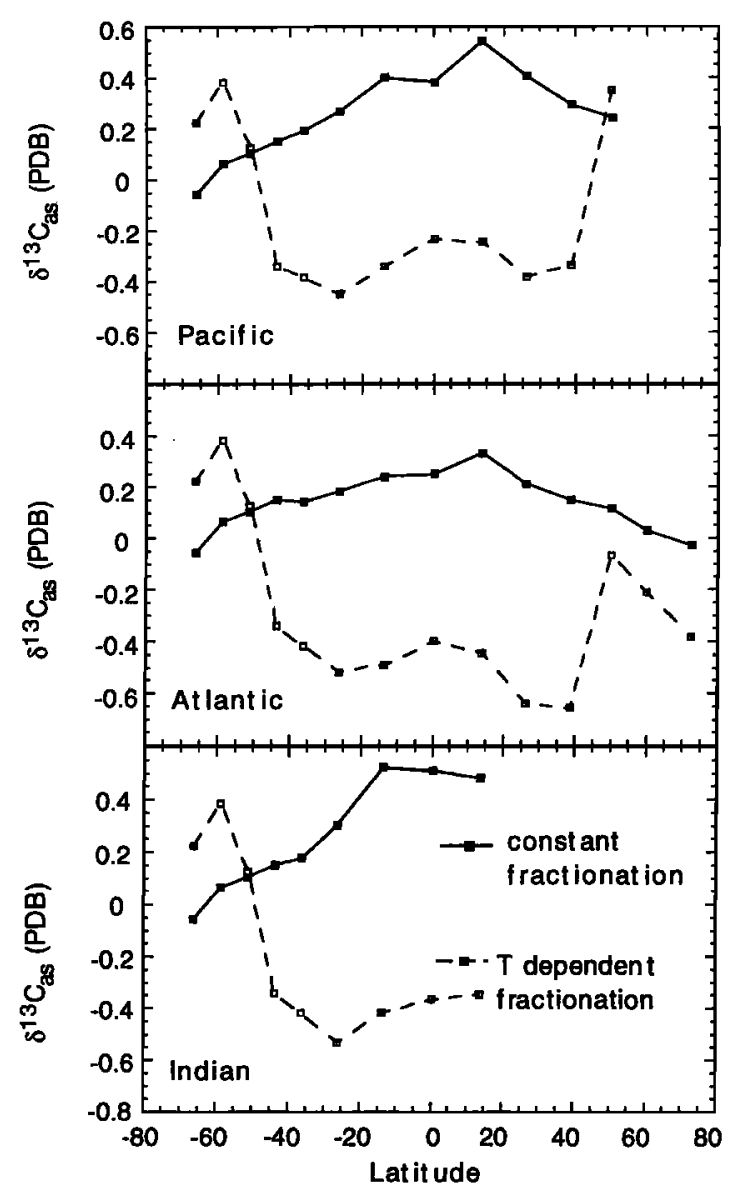

Figure 14. The $\delta^{13} \mathrm{C}_{\text {as }}$ of surface water for experiment 4, isotopic fractionation constant (solid lines and symbols). Variations in $\delta^{13} \mathrm{C}_{\mathrm{as}}$ are caused by the invasion and evasion of $\mathrm{CO}_{2}$ to/from the surface ocean. Also plotted for comparison is the $\delta^{13} C_{\text {as }}$ of surface water for experiment 1 , where isotopic fractionation is temperature dependent (dashed lines, open symbols). 
primarily due to the tendency toward isotopic equilibration between the ocean and atmospheric carbon reservoirs. The one-way transfer of isotopically light $\mathrm{CO}_{2}$ to and from the oceanic $\mathbf{\Sigma} \mathrm{CO}_{2}$ reservoir can also significantly affect surface ocean $\delta^{13} \mathrm{C}$. The importance of air-sea exchange on $\delta^{13} \mathrm{C}$ of surface waters can be seen in the departures from biologically predicted $\delta^{13} \mathrm{C}$ values in the surface ocean. Surface waters in the Southern Ocean have high $\delta^{13} \mathrm{C}$ anomalies due to isotopic exchange at low temperatures. Surface waters in the subtropical gyres have low $\delta^{13} \mathrm{C}$ anomalies due to isotopic exchange at high temperatures, while surface waters at the equator have high $\delta^{13} \mathrm{C}$ anomalies due to the evasion of $\mathrm{CO}_{2}$. In the North Atlantic, surface waters have low $\delta^{13} \mathrm{C}$ anomalies reflecting the warm surface water history and invasion of isotopically light atmospheric $\mathrm{CO}_{2}$. These anomalies are carried to deep sea from the region of water mass formation. The departure from biologically predicted $\delta^{13} \mathrm{C}$ can be quite large, and at times in the past the modern inverse relationship between deep water nutrient concentration $\delta^{13} \mathrm{C}$ could have changed if the oceans were filled with water masses originating in different surface regimes with different temperature and nutrient histories [Lynch-Stieglitz and Fairbanks, 1994]

Acknowledgments. This work was supported by Department of Energy grant DE-FG02-91ER61202 (Health and Environmental Research Program, Office of Energy Research) to TFS and WSB and Lamont-Doherty Earth Observatory Contribution 5421. We thank Robin Keir as well as two anonymous reviewers for helpful comments.

\section{References}

Broecker, W.S., and E. Maier-Reimer, The influence of air and sea exchange on the carbon isotope distribution in the sea, Global Biogeochem. Cycles, 6, 315-320, 1992.

Broecker, W.S., and T.-H. Peng, Gas exchange rates between air and sea, Tellus, 26, 21-35, 1974.

Broecker, W.S., and T.-H. Peng, Tracers in the Sea, Eldigio, Palisades, New York, 1982.

Broecker, W.S. and T.-H. Peng, Interhemispheric transport of carbon dioxide by ocean circulation, Nature, 356, 587-589, 1992.

Charles, C.D. and R.G. Fairbanks, Glacial to interglacial changes in the isotopic gradients of Southern Ocean surface water, in Geological History of the Polar Oceans: Arctic Versus Antarctic, edited by U. Bleil and J. Thiede, pp. 519-538, Kluwer Academic, Norwell, Mass., 1990.

Charles, C.D., J.D. Wright and R.G. Fairbanks, Thermodynamic Influences on the marine carbon isotope record, Paleoceanography, 8, 691-697, 1993.

Craig, H., Abyssal Carbon 13 in the South Pacific, J. Geophys. Res., 75, 691-695, 1970.

Deuser, W.G., and J.M. Hunt, Stable isotope ratios of dissolved inorganic carbon in the Atlantic, Deep Sea Res. Oceanogr. Abstr., 16, 221-225, 1969.

Esbensen, S.K, and Y. Kushnir, The heat budget of the global oceans: An atlas based on estimates from the surface marine observations, Clim. Res. Inst. Rep. 29, Oreg. State Univ., Corvallis, Oreg., 1981.

Friedli, H., H. Lötscher, H. Oeschger, U. Siegenthaler and B. Stauffer, Ice core record of the ${ }^{13} \mathrm{C} /{ }^{12} \mathrm{C}$ ratio of atmospheric $\mathrm{CO}_{2}$ in the past two centuries, Nature, 324, 237-238, 1986.

Gordon, A.L., Spatial and temporal variability within the Southern Ocean, in Antarctic Ocean and Resources Variability, edited by D. Sahrhage, pp. 41-56, Springer-Verlag, New York, 1988.

Inoue, $\mathrm{H}$. and $\mathrm{Y}$. Sugimura, Carbon isotopic fractionation during $\mathrm{CO}_{2}$ exchange process between air and sea water under equilibrium and kinetic conditions, Geochim. Cosmochim. Acta, 49, 2453-2460, 1985.

Jähne, B., G. Heinz, and W. Dietrich, Measurement of the diffusion coefficients of sparingly soluble gases in water, J. Geophys. Res., 92, 10,767-10,776, 1987.
Keeling, C.D, R.B. Bacastow, A.F. Carter, S.C. Piper, T.P. Whorf, M. Heimann, W.G. Mook, and H. Roeloffzen, A three dimensional model of atmospheric $\mathrm{CO}_{2}$ transport based on observed winds: 1 . Analysis of observational data, in Aspects of Climate Variability in the Pacific and the Western Americas. American Geophysical Union, Washington, DC, 165-236, 1989.

Keir, R.S. The effect of vertical nutrient redistribution on surface ocean $\delta^{13} \mathrm{C}$, Global Biogeochem. Cycles, 5, 351-358, 1991.

Keir, R.S. Are atmospheric $\mathrm{CO}_{2}$ content and Pleistocene climate connected by wind speed over a polar Mediterranean Sea?, Global Planet. Change, 8, 59-68, 1993.

Knox, M., P.D. Quay, and D. Wilbur, Kinetic isotopic fractionation during air-water gas transfer of $\mathrm{O}_{2}, \mathrm{~N}_{2}, \mathrm{CH}_{4}$, and $\mathrm{H}_{2}, J$. Geophys. Res., 97, 20,335-20,343, 1992.

Kroopnick, P.M., Correlations between ${ }^{13} \mathrm{C}$ and $\Sigma \mathrm{CO}_{2}$ in surface waters and atmospheric $\mathrm{CO}_{2}$, Earth Planet. Sci. Lett., 22, 397-403, 1974.

Kroopnick, P.M., The distribution of ${ }^{13} \mathrm{C}$ in the Atlantic Ocean, Earth Planet. Sci. Lett., 49, 469-484, 1980.

Kroopnick, P.M., The distribution of ${ }^{13} \mathrm{C}$ of $\Sigma \mathrm{CO}_{2}$ in the world oceans, Deep Sea Res. Part A, 32, 57-84, 1985.

Kroopnick, P., W.G. Deuser, and H. Craig, Carbon 13 measurements on dissolved inorganic carbon at the North Pacific (1969) GEOSECS station, J. Geophys. Res, 75, 7668-7671, 1970.

Kroopnick, P., R.F. Weiss, and $\mathrm{H}$. Craig, Total $\mathrm{CO}_{2},{ }^{13} \mathrm{C}$ and dissolved oxygen ${ }^{18} \mathrm{O}$ at GEOSECS II in the North Atlantic, Earth Planet. Sci. Lett., 16, 103-110, 1972.

Kroopnick, P.M., S.V. Margolis, and C.S. Wong, $\delta^{13} \mathrm{C}$ variations in marine carbonate sediments as indicators of the $\mathrm{CO}_{2}$ balance between the atmosphere and oceans, in The Fate of Fossil Fuel in the Oceans, edited by N.R. Anderson and A. Malahoff, pp. 295-321, Plenum, New York, 1977

Levitus, S., Climatological atlas of the world ocean, NOAA Prof. Pap. 13,177 pp., 1982.

Lynch-Stieglitz, J., and R.G. Fairbanks, A conservative tracer for glacial ocean circulation from carbon isotope and palaeo-nutrient measurements in benthic foraminifera, Nature, 369, 308-310, 1994.

Mackensen, A., H.-W. Hubberton, T. Bickert, G. Fischer, and D.K. Futterer, The $\delta^{13} \mathrm{C}$ in benthic foraminiferal tests of Fontbotia wuellerstorfi (Schwager) relative to the $\delta^{13} \mathrm{C}$ of dissolved inorganic carbon in Southern Ocean deep water: Implications for glacial ocean circulation models, Paleoceanography, 6, 587-610, 1993.

Mook, W.G., J.C. Bommerson, and W.H. Staverman, Carbon isotope fractionation between dissolved bicarbonate and gaseous carbon dioxide, Earth Planet. Sci. Lett., 22, 169-176, 1974.

Oppo, D.W., and R.G. Fairbanks, Carbon isotope composition of tropical surface water during the past 22,000 years, Paleoceanography, 4, 333-351, 1989.

Ostlund, H.G., and C. Grall, Transient tracers in the ocean, North and Tropical Atlantic tritium and radiocarbon, Data Rep. 16, Tritium Lab., Rosenstiel Sch. on Mar. and Atmos. Sci., Univ. of Miami, Miami, Fla., 1987.

Rau, G.H., T. Takahashi, and D.J. Des Marais, Latitudinal variations in plankton $\delta^{13} \mathrm{C}$ : Implications for $\mathrm{CO}_{2}$ and productivity in past oceans, Nature, 341, 516-518, 1989.

Rau, G.H., P.N. Froelich, T. Takahashi, and D.J. Des Marais, Does sedimentary organic $\delta^{13} \mathrm{C}$ record variations in Quaternary Ocean $\left[\mathrm{CO}_{2}\right.$ (aq)]?, Paleoceanography, 6, 335-347, 1991.

Siegenthaler, U., and K.O. Munnich, ${ }^{13} \mathrm{C} /{ }^{12} \mathrm{C}$ fractionation during $\mathrm{CO}_{2}$ transfer from air to sea, in Carbon Cycle Modelling, edited by $\mathrm{B}^{2}$. Bolin, pp. 249-257, John Wiley, New York, 1981.

Stocker, T.F., W.S. Broecker, and D.G. Wright, Carbon uptake experiments with a zonally-averaged global ocean circulation model, Tellus, 46B, 103-122, 1994.

Tans, P.P., On calculating the transfer of carbon-13 in reservoir models of the carbon cycle, Tellus, 32, 464-469, 1980.

Tans, P.P., I.Y. Fung, and T. Takahashi, Observational constraints on the global atmospheric $\mathrm{CO}_{2}$ budget, Science, 247, 143I-1438, 1994.

Vogel, J.G., P.M. Grootes, and W.G. Mook, Isotopic fractionation between gaseous and dissolved carbon dioxide, $Z$. Phys, 230, 225238,1970 .

Wanninkhof, R., Kinetic fractionation of the carbon isotopes ${ }^{13} \mathrm{C}$ and ${ }^{12} \mathrm{C}$ during transfer of $\mathrm{CO}_{2}$ from air to seawater, Tellus, 37B, 128135,1985 . 
Wright, D.G., and T.F. Stocker, Sensitivities of a zonally averaged global ocean circulation model, J. Geophys. Res., 97, 12,707-12,730, 1992.

Zahn, R., and R. Keir, Tracer-nutrient correlations in the upper ocean: Observational and box model constraints on the use of benthic foraminiferal $\delta^{13} \mathrm{C}$ and $\mathrm{Cd} / \mathrm{Ca}$ as paleo-proxies for the intermediatedepth ocean, in Carbon Cycling in the Glacial Ocean: Constraints on the Ocean's role in global change, edited by R. Zahn et al., pp. 195221, Springer-Verlag, New York, 1994.

Zhang, J., Quay, P.D. and D.O Wilbur, Carbon isotope fractionation during gas-water exchange and dissolution of $\mathrm{CO}_{2}$, Geochim. et Cosmochim. Acta, 59, 107-114, 1995.
W.S. Broecker and R.G. Fairbanks, Lamont-Doherty Earth Observatory and Department of Geological Sciences, Columbia University, Palisades, NY 10964. (e-mail: broecker@ldeo.columbia.edu; fairbank@Ideo.co.umbia.edu)

J. Lynch-Stieglitz, Woods Hole Oceanographic Institution, Woods Hole MA 02543. (e-mail: jean @cod.whoi.edu)

T.F. Stocker, Climate and Environmental Physics, Physics Institute, University of Bern, Sidlerstrasse 5, 3012 Bern, Switzerland. (e-mail: stocker@climate.unibe.ch)

(Received April 26, 1994; revised August 17, 1995; accepted August 22, 1995.) 